Article

\title{
A Study of the Socioeconomic Forces Driving Air Pollution Based on a DPSIR Model in Henan Province, China
}

\author{
Xiaoming Chuai ${ }^{1, *}$, Chao Fan ${ }^{1}$, Mingshi Wang ${ }^{2, *}$, Jiajia Wang ${ }^{1}$ and Yanjun Han ${ }^{1}$ \\ 1 Safety and Emergency Management Research Center, Henan Polytechnic University, Jiaozuo 454003, China; \\ fanchao1207@163.com (C.F.); wangjia8587@126.com (J.W.); Han_yj729@163.com (Y.H.) \\ 2 Institute of Resources \& Environment, Henan Polytechnic University, Jiaozuo 454003, China \\ * Correspondence: chuaixm@hpu.edu.cn (X.C.); mingshiwang78@hotmail.com (M.W.); Tel.: +86-391-398-6559 \\ or +86-150-3915-0856 (X.C.); +86-134-6244-8199 (M.W.)
}

Received: 27 October 2019; Accepted: 26 December 2019; Published: 27 December 2019

\begin{abstract}
The 3D spatiotemporal distribution (spatial and annual-month-daily temporal) features of the air quality index (AQI), air pollutants $\left(\mathrm{PM}_{2.5}, \mathrm{PM}_{10}, \mathrm{SO}_{2}, \mathrm{NO}_{2}, \mathrm{CO}\right.$, and $\mathrm{O}_{3}-8 \mathrm{~h}$ ), and air pollution risks $(\mathrm{R})$ from 2003 to 2018 were investigated to understand the severity of air pollution in Henan province. The multiyear ascending trends for AQI and $\mathrm{R}$ values, with a peak in 2015, were observed in 2003 to 2018 since the annual population-weighted average concentrations of $\mathrm{PM}_{2.5}, \mathrm{PM}_{10}, \mathrm{NO}_{2}$, and $\mathrm{O}_{3}-8 \mathrm{~h}$ were always higher than the CAAQs II from 2013 to 2017 in Henan province. Changes in the monthly moving average AQI values in Henan province conformed to a U-shaped pattern, with the highest values in the winter (from December to February) and the lowest in the summer (from June to August). Triple peaks for AQI values of 8:00-10:00 a.m., 6:00-8:00 p.m., and 2:00-4:00 p.m. in the representative municipalities corresponded with the morning and evening traffic tendencies and photochemical process. A spatial analysis indicated that there were decreasing trends for air pollution from northwest to southeast in Henan province. Data on 48 concrete parameters were collected from 2003 to 2017 to construct a driving force-pressure-state-influence-response (DPSIR) model for assessing the socioeconomic forces driving air pollution in this province. It was the too-rapid growth of the driving force index (DFI), induced by urban development and population growth (UDPG), economic growth and change of industrial structure (EGCIS), and energy consumption growth and structure change (ECGSC), that led to a direct increase in the atmospheric pollution burden, i.e., total emissions from air pollution and industrial emissions, which are linearly correlated to values of UDPG and ECGSC, respectively $(p<0.05)$. Furthermore, the prediction models for AQI and R values in Henan province, with the growth rates being $4.251 \mathrm{DFI}^{-1}$ and $0.0816 \mathrm{DFI}^{-1}$, respectively, were simulated by multiple linear regression analysis. Therefore, the integrated risks of air pollution in Henan province were originally driven by DFI.
\end{abstract}

Keywords: DPSIR model; driving force; 3D spatiotemporal features; air pollution; integrated risk

\section{Introduction}

As the fastest-growing major economy in the world, China has been increasingly threatened by environmental deterioration due to rapid economic growth, unprecedented urbanization, and climatic conditions in the past three decades [1]. In 2013, the annual average $\mathrm{PM}_{2.5}$ concentrations in $93.2 \%$ of 74 key monitored cities in China were higher than $35 \mu \mathrm{g} / \mathrm{m}^{3}$ (the maximum level set by the World Health Organization), leading to adverse impacts on atmospheric visibility, human health, traffic, fires, and even social stability [2-7]. The Action Plan for Air Pollution Prevention and Control was rolled out in 2013 to mitigate air pollution levels in China. However, the frequent occurrence of extreme haze 
episodes throughout the country in 2014 to 2018 triggered the Chinese government to take measures to tackle the serious air quality problems. Serious haze pollutions occurring in many cities of China, such as Beijing, Tianjin, Shijiazhuang, Shenyang, Changchun, Haerbin, Jinan, Zhengzhou, Xingtai, Baoding, Tangshan, Hengshui, Anyang, Linfen, and so on, which are predominantly characterized by high concentrations of fine particulate matter $\left(\mathrm{PM}_{2.5}\right)$, have raised concern around the world [8-12].

To eliminate or alleviate the detrimental effects of air pollution, a series of measures, including end-of-pipe emission technologies exploitation, fuel consumption efficiencies improvement, implementation of industrial energy-saving and emission-reduction policies, and the formulation of much stricter standards, as well as the promulgation of the Action Plan for Air Pollution Prevention and Control, has been taken by the Chinese government in the past few years. However, ambient air quality is still a major concern in China since severe and persistent air pollution in different regions remains an obstacle to public health, economic growth, public safety, and social stability $[9,10,13,14]$. Thus, the formation mechanism for air pollution and its influence factors, especially the socioeconomic influence factors, are worth investigating further. The industrial structure and its growth rate, the energy consumption structure and the corresponding consumption intensity, vehicular emissions, urban expansion, and population were predicted to be the key socioeconomic factors affecting the changes in air pollutant emissions over the period [15-18]. Energy consumption and transportation affected the air pollution level in Europe [17]. The urban expansion, economic growth and its structure change, energy consumption structure, motor vehicle use, population size and density were supposed to be the key influence factors for Chinese air pollutions by Liu et al. [1], Wang et al. [13], Lyu et al. [15], Azimi et al. [18], and Basagaña et al. [19]. The gross domestic product (GDP) and population were found to be significantly correlated with the benefit-cost ratio value, which was utilized to verify the feasibility and validity of industrial energy-saving and emission-reduction policies in the Air Pollution Prevention and Control Action Plan in 2013 [20]. In addition, the effects of public transportation strikes on air pollution levels in Barcelona (Spain) were researched by Basagaña et al. (2018) [19]. Ning et al. (2018) studied the effect of topographical conditions on characteristics of air pollution in Sichuan Basin, China [21].

As the most crucial component of the Central Plain Urban Agglomeration (CPUA) region, Henan province has been one of the most severely polluted regions in China in recent years [22], i.e., its air quality was among the worst in all the provinces in China, and its provincial capital city, Zhengzhou, was listed among "the top ten worst for air quality" in China from 2013 to 2017. However, relatively little attention has been paid to this problem, excluding Liu et al. [1], who provided an integrated atmospheric emissions inventory of primary air pollutants for the target year of 2012.

In this study, the spatial and three-dimensional temporal scale features for air quality in the 17 municipalities of Henan province, China, were analyzed from 2003 to 2018. Data on the 48 concrete parameters (including air quality index (AQI) values, $\mathrm{SO}_{2}$ contents, $\mathrm{NO}_{2}$ contents, $\mathrm{PM}_{10}, \mathrm{PM}_{2.5}$, $\mathrm{CO}, \mathrm{O}_{3}$, total emission amount of $\mathrm{SO}_{2}, \mathrm{NO}_{\mathrm{x}}$ and waste gas, temperature, precipitation, wind power, population, urbanization, GDP, per capita GDP (PCGDP), vehicle population, primary industry $\left(E G_{2}\right)$, secondary industry $\left(E G_{3}\right)$, tertiary industry $\left(E G_{4}\right)$, industry $\left(E G_{5}\right)$, construction $\left(E G_{6}\right)$, tourism $\left(E G_{7}\right)$, ratios for $E G_{2} / G D P, E G_{3} / G D P$ and $E G_{4} / G D P$, living energy consumption $\left(E S_{1}\right)$, living raw coal consumption $\left(E S_{2}\right)$, living power consumption $\left(E S_{3}\right)$, energy consumption of scale-enterprise $\left(E S_{4}\right)$, raw coal consumption of scale-enterprise $\left(E S_{5}\right)$, thermal consumption of scale-enterprise $\left(E S_{6}\right)$, power consumption of scale-enterprise $\left(E S_{7}\right)$, ratios for $E S_{2} / E S_{1}, E S_{3} / E S_{1}, E S_{5} / E S_{4}, E S_{6} / E S_{4}, E S_{7} / E S_{4}$, death toll from traffic accidents, injury from traffic accidents, passenger turnover quantities, freight turnover quantities, fire disasters, and death populations of cancer, respiratory diseases, heart diseases, and nervous system diseases) from 2003 to 2017 were collected to quantitatively evaluate the socioeconomic forces driving air pollution in this province using a driving forces-pressure-state-influence-response (DPSIR) model. 


\section{Materials and Methods}

\subsection{Study Area}

Henan province, located in central China, is a crucial transition zone from the developed coastal areas and western undeveloped areas. Due to high population accumulation, rapid economic growth rate, a coal-based energy consumption structure, and a fast urbanization process, the air quality in most cities of Henan province, such as Zhengzhou, Anyang, Pingdingshan, Jiaozuo, and Luoyang, has worsened in recent years. Therefore, the 17 municipalities of Henan Province, including Zhengzhou (ZZ), Kaifeng (KF), Luoyang (LY), Xinyang (XY), Anyang (AY), Pingdingshan (PDS), Zhumadian (ZMD), Jiaozuo (JZ), Zhoukou (ZK), Sanmenxia (SMX), Xinxiang (XX), Puyang (PY), Hebi (HB), Shangqiu (SQ), Xuchang (XC), Luohe (LH), and Nanyang (NY), were chosen to investigate the formation mechanism of urban air pollution risk based on a DPSIR model in Henan province, China (Figure 1).

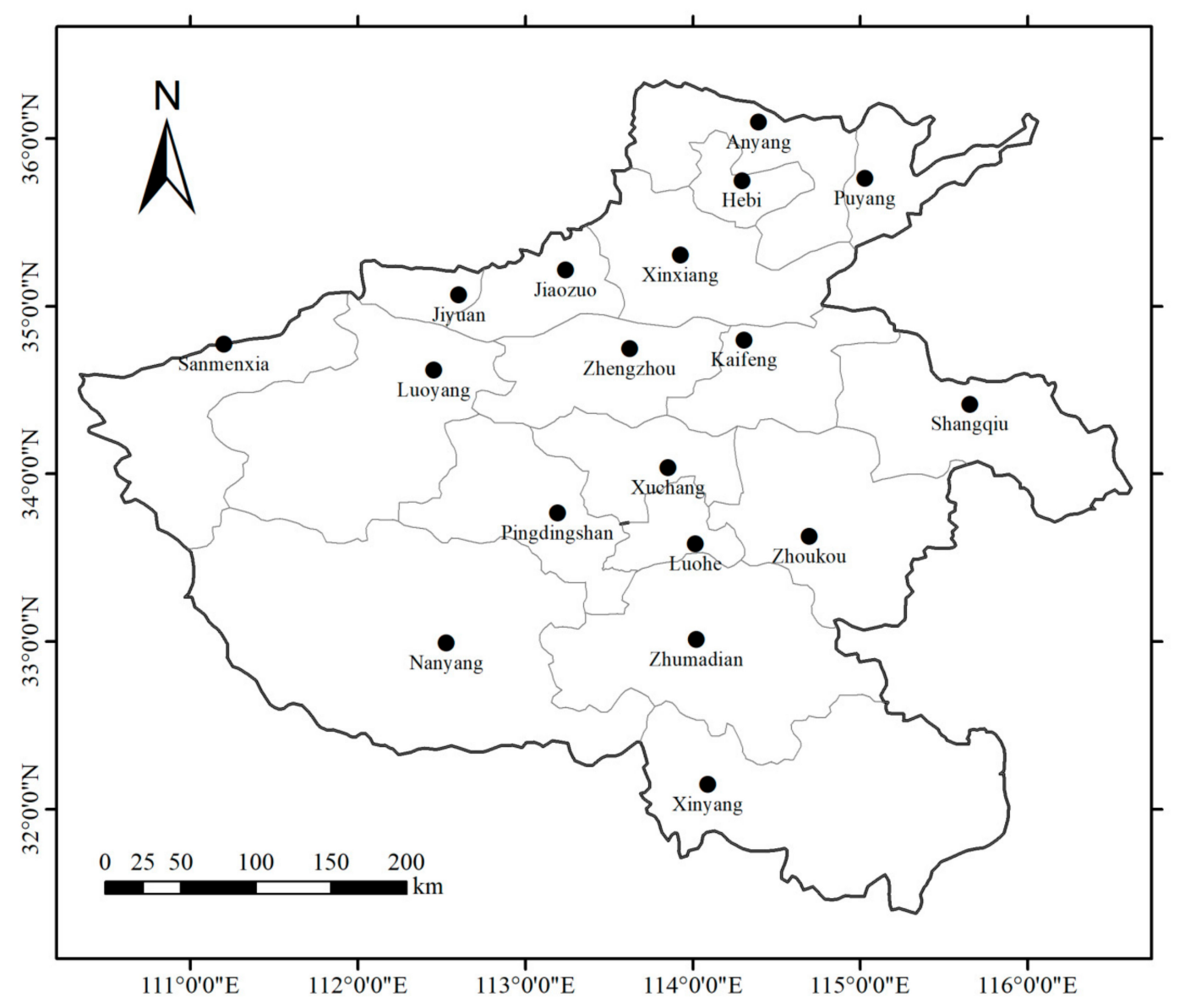

Figure 1. Study area.

\subsection{Data Sources}

The AQI values of the 17 municipalities of Henan province from 2003 to 2018 were taken from the official website of Ministry of Ecology and Environment of the People's Republic of China (Table 1). The historical data for most influence factors, including population $\left(U D_{1}\right)$, urbanization $\left(U D_{2}\right), G D P$ $\left(U D_{3}-E G_{1}\right)$, PCGDP $\left(U D_{4}\right)$, vehicle population $\left(U D_{5}\right)$, primary industry $\left(E G_{2}\right)$, secondary industry $\left(E G_{3}\right)$, tertiary industry $\left(E G_{4}\right)$, industry $\left(E G_{5}\right)$, construction $\left(E G_{6}\right)$, tourism $\left(E G_{7}\right)$, etc., were collected from the Henan Statistical Yearbook (Table 1). The concentrations of $\mathrm{SO}_{2}, \mathrm{NO}_{2}, \mathrm{PM}_{10}, \mathrm{PM}_{2.5}, \mathrm{CO}$, and $\mathrm{O}_{3}$ in the 17 municipalities of Henan province were obtained from the Reports on Environment States in Henan Province, 1999 to 2018 (Table 1). All these data were collected from Ministry of Ecology and Environment of the People's Republic of China, the Henan Statistical Yearbook, and Reports on Environment 
states in Henan Province, which contain official data provided by professional authority sectors, such as the China National Environmental Monitoring Centre, the Henan Province Bureau of Statistics, and the Department of Ecology and Environment of Henan Province.

Table 1. The influence factors for air pollution in Henan province.

\begin{tabular}{|c|c|c|}
\hline Modules & Influence Factors & Data Sources \\
\hline \multirow{3}{*}{$\begin{array}{l}\text { Atmospheric } \\
\text { Quality Status }\end{array}$} & AQI & $\begin{array}{l}\text { Ministry of Ecology and Environment of the } \\
\text { People's Republic of China }\end{array}$ \\
\hline & $\begin{array}{l}\text { Concentrations of Air Pollutants }\left(\mathrm{SO}_{2}, \mathrm{NO}_{\mathrm{x}}\right. \\
\left.\qquad \mathrm{PM}_{10}, \mathrm{PM}_{2.5}, \mathrm{CO}, \mathrm{O}_{3}\right)\end{array}$ & $\begin{array}{l}\text { 1999-2017 Reports on Environment States } \\
\text { in Henan Province }\end{array}$ \\
\hline & $\begin{array}{l}\text { Total Emission amount of air pollutants }\left(\mathrm{SO}_{2},\right. \\
\qquad \mathrm{NO}_{\mathrm{x}} \text {, Waste Gas) }\end{array}$ & 2004-2018 Henan Statistical Yearbook \\
\hline \multirow{3}{*}{$\begin{array}{l}\text { Meteorological } \\
\text { Conditions }\end{array}$} & Temperature $\left(\mathrm{MC}_{1}\right)$ & Henan Meteorological Bureau \\
\hline & Precipitation $\left(\mathrm{MC}_{2}\right)$ & Henan Water Resources Bulletin \\
\hline & Wind power $\left(\mathrm{MC}_{3}\right)$ & Henan Meteorological Bureau \\
\hline \multirow{5}{*}{$\begin{array}{c}\text { Urban } \\
\text { Development and } \\
\text { Population Growth } \\
\text { (UDPG) }\end{array}$} & Population $\left(\mathrm{UD}_{1}\right)$ & 2004-2018 Henan Statistical Yearbook \\
\hline & Urbanization $\left(\mathrm{UD}_{2}\right)$ & 2004-2018 Henan Statistical Yearbook \\
\hline & GDP (UD3-EG 1 ) & 2004-2018 Henan Statistical Yearbook \\
\hline & PCGDP $\left(\mathrm{UD}_{4}\right)$ & 2004-2018 Henan Statistical Yearbook \\
\hline & Vehicle Population $\left(\mathrm{UD}_{5}\right)$ & 2004-2018 Henan Statistical Yearbook \\
\hline \multirow{10}{*}{$\begin{array}{l}\text { Economic Growth } \\
\text { and Change of } \\
\text { Industrial Structure } \\
\text { (EGCIS) }\end{array}$} & GDP (UD3-EG 1 ) & 2004-2018 Henan Statistical Yearbook \\
\hline & Primary Industry $\left(\mathrm{EG}_{2}\right)$ & 2004-2018 Henan Statistical Yearbook \\
\hline & Secondary Industry $\left(\mathrm{EG}_{3}\right)$ & 2004-2018 Henan Statistical Yearbook \\
\hline & Tertiary Industry $\left(\mathrm{EG}_{4}\right)$ & 2004-2018 Henan Statistical Yearbook \\
\hline & Industry $\left(\mathrm{EG}_{5}\right)$ & 2004-2018 Henan Statistical Yearbook \\
\hline & Construction $\left(\mathrm{EG}_{6}\right)$ & 2004-2018 Henan Statistical Yearbook \\
\hline & Tourism $\left(\mathrm{EG}_{7}\right)$ & 2004-2018 Henan Statistical Yearbook \\
\hline & Ratios for $\mathrm{IS}_{2} / \mathrm{IS}_{1}\left(\mathrm{EG}_{8}\right)$ & 2004-2018 Henan Statistical Yearbook \\
\hline & Ratios for $\mathrm{IS}_{3} / \mathrm{IS}_{1}\left(\mathrm{EG}_{9}\right)$ & 2004-2018 Henan Statistical Yearbook \\
\hline & Ratios for $\mathrm{IS}_{4} / \mathrm{IS}_{1}\left(\mathrm{EG}_{10}\right)$ & 2004-2018 Henan Statistical Yearbook \\
\hline \multirow{12}{*}{$\begin{array}{c}\text { Energy } \\
\text { Consumption } \\
\text { Growth and } \\
\text { Structure Change } \\
\text { (ECGSC) }\end{array}$} & Living Energy Consumption $\left(\mathrm{ES}_{1}\right)$ & Compute \\
\hline & Living Raw Coal Consumption $\left(\mathrm{ES}_{2}\right)$ & 2004-2018 Henan Statistical Yearbook \\
\hline & Living Power Consumption $\left(\mathrm{ES}_{3}\right)$ & 2004-2018 Henan Statistical Yearbook \\
\hline & Energy Consumption of Scale-Enterprise $\left(\mathrm{ES}_{4}\right)$ & 2004-2018 Henan Statistical Yearbook \\
\hline & Raw Coal Consumption of Scale-Enterprises $\left(\mathrm{ES}_{5}\right)$ & 2004-2018 Henan Statistical Yearbook \\
\hline & Thermal Consumption of Scale-Enterprises $\left(\mathrm{ES}_{6}\right)$ & 2004-2018 Henan Statistical Yearbook \\
\hline & Power Consumption of Scale-Enterprises $\left(\mathrm{ES}_{7}\right)$ & 2004-2018 Henan Statistical Yearbook \\
\hline & Ratio for $\mathrm{ES}_{2} / \mathrm{ES}_{1}\left(\mathrm{ES}_{8}\right)$ & Compute \\
\hline & Ratio for $\mathrm{ES}_{3} / \mathrm{ES}_{1}\left(\mathrm{ES}_{9}\right)$ & Compute \\
\hline & Ratio for $\mathrm{ES}_{5} / \mathrm{ES}_{4}\left(\mathrm{ES}_{10}\right)$ & Compute \\
\hline & Ratio for $\mathrm{ES}_{6} / \mathrm{ES}_{4}\left(\mathrm{ES}_{11}\right)$ & Compute \\
\hline & Ratio for $\mathrm{ES}_{7} / \mathrm{ES}_{4}\left(\mathrm{ES}_{12}\right)$ & Compute \\
\hline \multirow{3}{*}{ Public Impact } & Public traffic Accidents & 2004-2018 Henan Statistical Yearbook \\
\hline & Fire Disaster & 2004-2018 Henan Statistical Yearbook \\
\hline & Related Diseases & Compute \\
\hline
\end{tabular}

The living energy consumption $\left(E S_{j}\right)$ and death population for related diseases $\left(R D_{j}\right)$ in the 17 municipalities in a year were computed by Equations (1) and (2):

$$
\begin{gathered}
E S_{j}=E S_{0} \times U D_{1 j} \\
R D_{j}=R D_{i o} \times U D_{1 j}
\end{gathered}
$$

$E S_{0}$ is the daily per capita living energy consumption in Henan province, $\mathrm{kg}$ of standard coal.person ${ }^{-1} . R D_{i o}$ represents the mortality of the $i$ th disease in Henan province, persons ${ }^{-1} . U D_{1 j}$ represents the population of $j$ municipality in Henan province, $j=1,2,3, \ldots, 17$, person

$$
\mathrm{R}=\sum_{i=1}^{7}\left(P_{i} \times C_{i}\right)
$$




$$
P_{i}=D A Y_{i} / D A Y_{t}
$$

In order to calculate the integrated risk $(\mathrm{R})$ values, AQI values were divided into seven grades, that is, the AQI value intervals were $(0,100],(100,150],(150,200],(200,300],(300,400],(400,500]$, and $(500,+\infty]$, respectively, when $i=1,2, \ldots, 7 . P_{i}$ and $C_{i}$ represent the probability and severity of air pollution when $i=1,2, \ldots, 7$. The severity of air pollution in Henan province was $0.25,1.5,2.5$, $3.5,4,4.5$, and 5 , respectively, as determined by 20 environmental experts (environmental professors with a doctoral degree) in China. $P_{i}$ was calculated by Equation (4). $D A Y_{i}$ and $D A Y_{t}$ were days for grade $i$ and the whole year, respectively. Finally, the air pollution risk (R) values were calculated by Equation (3) using the risk matrix method, which is a common risk assessment method [23].

\subsection{DPSIR Model}

Air pollution is a complex social-economic-environmental process and is increasingly drawing more and more attention from researchers around the world [24]. The 48 correlated influence factors were collected to evaluate the socioeconomic forces driving air pollution in Henan province using a DPSIR model, which was applied to determine the relationship between cause and effect of air pollution problems and status [25,26] (Figure 2), which included five interactive modules: (1) Driving Force, including urban development and population growth (UDPG), economic growth and change of industrial structure (EGCIS), as well as energy consumption growth and its structure change (ECGSC, Table 1); (2) Pollution Pressure, to which total emissions of air pollution (TEAP) and industrial emissions of air pollution (IEAP) made great contributions; (3) Pollution State, including annual concentrations of $\mathrm{SO}_{2}, \mathrm{NO}_{\mathrm{x}}, \mathrm{PM}_{2.5}, \mathrm{PM}_{10}, \mathrm{CO}$, and $\mathrm{O}_{3}-8 \mathrm{~h}$; (4) Influence, including traffic, fires, and related diseases; (5) Response, including the response of air pollution levels to social-economic-environmental changes in Henan province.

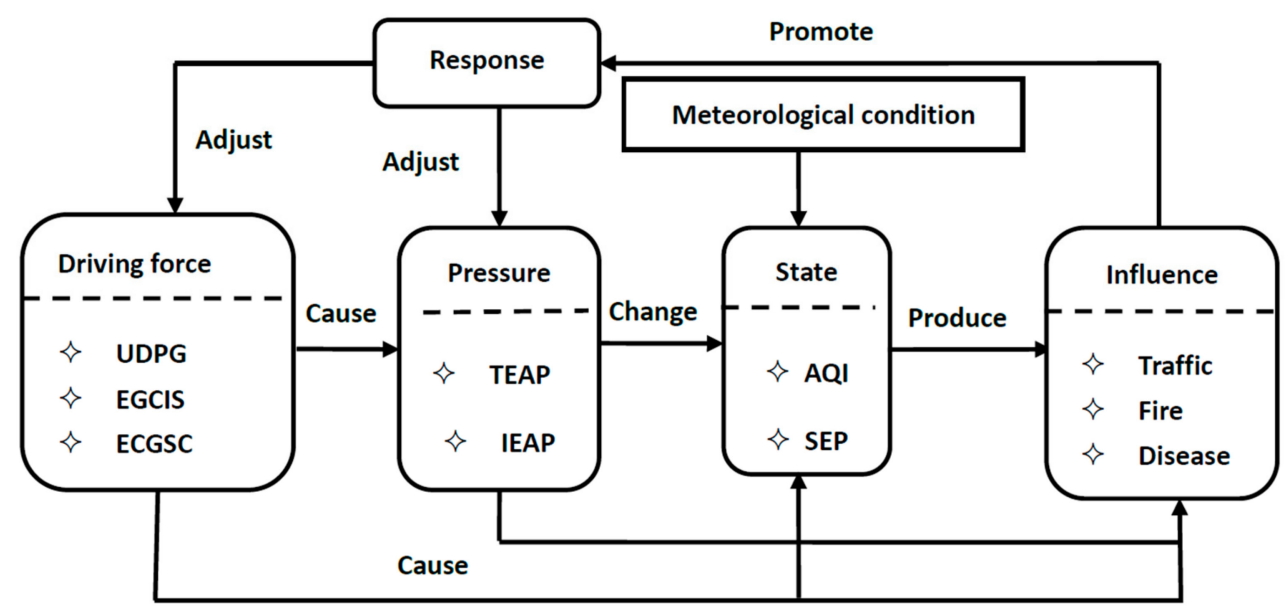

Figure 2. Driving force-pressure-state-influence-response (DPSIR) model for air pollution (UDPG: Urban Development and Population Growth; EGCIS: Economic Growth and Change of Industrial Structure; ECGSC: Energy Consumption Growth and Its Structure Change; TEAP: Total Emission of Air Pollution; IEAP: Industrial Emission of Air Pollution; SEP: six kinds of air pollutants, including $\mathrm{PM}_{2.5}, \mathrm{PM}_{10}, \mathrm{SO}_{2}, \mathrm{NO}_{2}, \mathrm{CO}$, and $\left.\mathrm{O}_{3}\right)$.

For this model, the increase of driving force was the root reason for the rise in the pollutants burden (Figure 2), which subsequently caused AQI and pollutant levels to rise a bit in a certain period. Actually, it was obvious that all the changes in driving force, pollutant burden, and pollutant contents would inevitably result in increased risk, including more traffic, more frequent fires, and an increased incidence of related diseases in the 17 municipalities of Henan province, China. 
Therefore, DPSIR model was a frame structural model for the socioeconomic forces driving air pollution in Henan province. The degree of correlations between air qualities and 48 concrete parameters by analysis methods which were discussed in Section 2.4. At the basis of these, quantitative relations between air pollution status (AQI, R, TEAP, IEAP) and socioeconomic forces driving air pollution in Henan province (DFI, UDPG, ECGSC) were simulated by the multiple linear regression analysis method using statistical analysis software SPSS 19.0.

\subsection{Statistical Method}

The correlations between AQI values and its influence factors in Henan province were analyzed by Pearson correlations using social statistical analysis software SPSS19.0. The principal component analysis (PCA) method was chosen to calculate the driving force index (DFI), UDPG, EGCIS, ECGSC, TEAP, IEAP, and passenger and freight turnover volume $(\mathrm{K}-\mathrm{H})$ values by the corresponding concrete parameters using SPSS19.0. The effect of influence factors on different modules was simulated by linear regression using SPSS 19.0.

\subsection{Data Standardized Treatment Method}

Taking the 2003 values as reference values, the relative ratio values for different influence factors in multiple years were calculated before the correlation and regression analysis in the 17 municipalities of Henan province. The spatial differences for AQI, over-standard days, and risk levels in Henan province in 2017 were drawn using Geography Drawing software Arcgis 10.0.

\section{Results}

The 3D spatiotemporal (spatial and annual-month-daily) features of air pollution in Henan province are analyzed in detail in Section 3.1. It was extensive air pollution that caused the baseline to change significantly in Henan province. Moreover, air pollution is aggravated if meteorological conditions are suitable (Figure 2).

\subsection{The 3D Temporal Characteristics of Air Pollution}

\subsubsection{AQI Value Variations}

The annual average air quality index (AQI) values for 2003-2018 in the 17 municipalities of Henan province are analyzed in Figure 3. Fluctuations in AQI values were observed in these municipalities from 2003 to 2012, followed by a dramatic increase to a peak in 2015 and a decreasing trend from 2015 to 2018, i.e., the AQI values for Zhengzhou in 2003, 2012, 2015, and 2018 were 78.46, 77.94, 134.76, and 115.62 , respectively. It was demonstrated that the annual average AQI values for all the municipalities were always higher than 100 (the second standard for HJ663-2013), except for Xinyang from 2016 to 2018. It was proven that intensive pollutant emissions, originating from rapid urbanization, an irrational industrial structure, the explosive growth of vehicles, and excessive energy consumption, were the main causes for this pollution status, i.e., the total discharge amounts of $\mathrm{SO}_{2}, \mathrm{NO}_{\mathrm{x}}$, and dust were 1.14, 1.25, and 0.85 million tons in Henan province in 2015 according to the Henan Statistical Yearbook. 

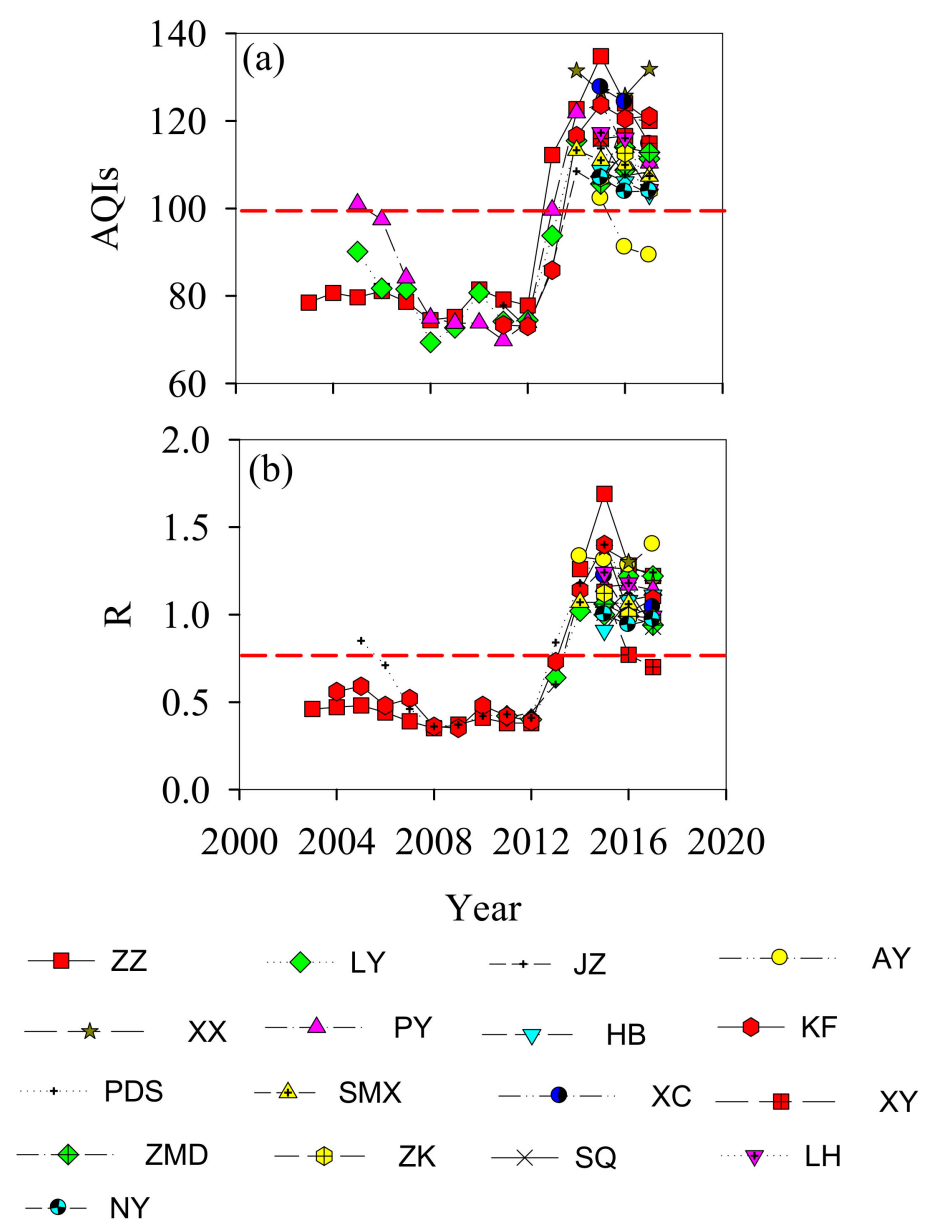

Figure 3. Multiyear changes of air quality index (AQI) (a) and air pollution risk (R) values (b) in the 17 municipalities of Henan province, P. R., China (ZZ: Zhengzhou; LY: Luoyang; JZ: Jizozuo; AY:Anyang; XX: Xinxiang; PY: Puyang; HB: Hebi; KF: Kaifeng; PDS: Pingdingshan; SMX: Sanmenxia; XC: Xuchang; XY: Xinyang; ZMD: Zhumadian; ZK: Zhoukou; SQ: Shangqiu; LH: Luohe; NY: Nanyang).

The multiyear series of AQI values in the 17 municipalities of Henan province showed discriminative seasonal differences (Figure $4, p<0.05$ ). A statistical analysis indicated that changes in the monthly moving average AQI values conformed to a U-shaped pattern, being the highest in the winter (from December to February) and the lowest in the summer (from June to August), which was consistent with the change trends for northern China discussed by Song et al. (2017) [9]. Although the annual average AQI values decreased from 2015 to 2018 (Figure 3), the AQI values in winter of the majority municipalities (including Zhengzhou, Kaifeng, Luoyang, Anyang, Pingdingshan, Jiaozuo, Puyang, Hebi, Xuchang, and Nanyang) in the winter of $2016(2017,2018)$ were much higher than those in 2014 and 2015. Furthermore, the average AQI values in the winter of all municipalities of Henan province exceeded the second standard for HJ663-2013 (100) in the winter of $2016(2017,2018)$, i.e., the AQI values were $179.28(136.89,148.71)$ for Zhengzhou, $141.13(137.47,159.20)$ for Kaifeng, 178.32 (123.09, 152.26) for Luoyang, 120.37 (118.71, 126.26) for Xinyang, 217.76 (153.56, 173.75) for Anyang, 161.35 (131.48, 150.71) for Pingdingshan, $139.76(125.10,131.80)$ for Zhumadian, $185.73(132.17,151.67)$ for Jiaozuo, 146.08 (135.97, 146.56) for Zhoukou, 145.28 (125.05, 144.58) for Sanmenxia, 166.15 (120.65, 139.70) for Xinxiang, 178.55 (137.32, 165.50) for Puyang, 174.42 (118.60, 137.31) for Hebi, 136.17 (137.13, 139.21) for Shangqiu, $163.53(136.39,161.72)$ for Xuchang, 159.72 (134.60, 159.63) for Luohe, and 137.02 $(146.70,164.60)$ for Nanyang, respectively. The winter monsoon and higher secondary aerosols were cited as the two main reasons for the phenomenon $[9,27]$. 


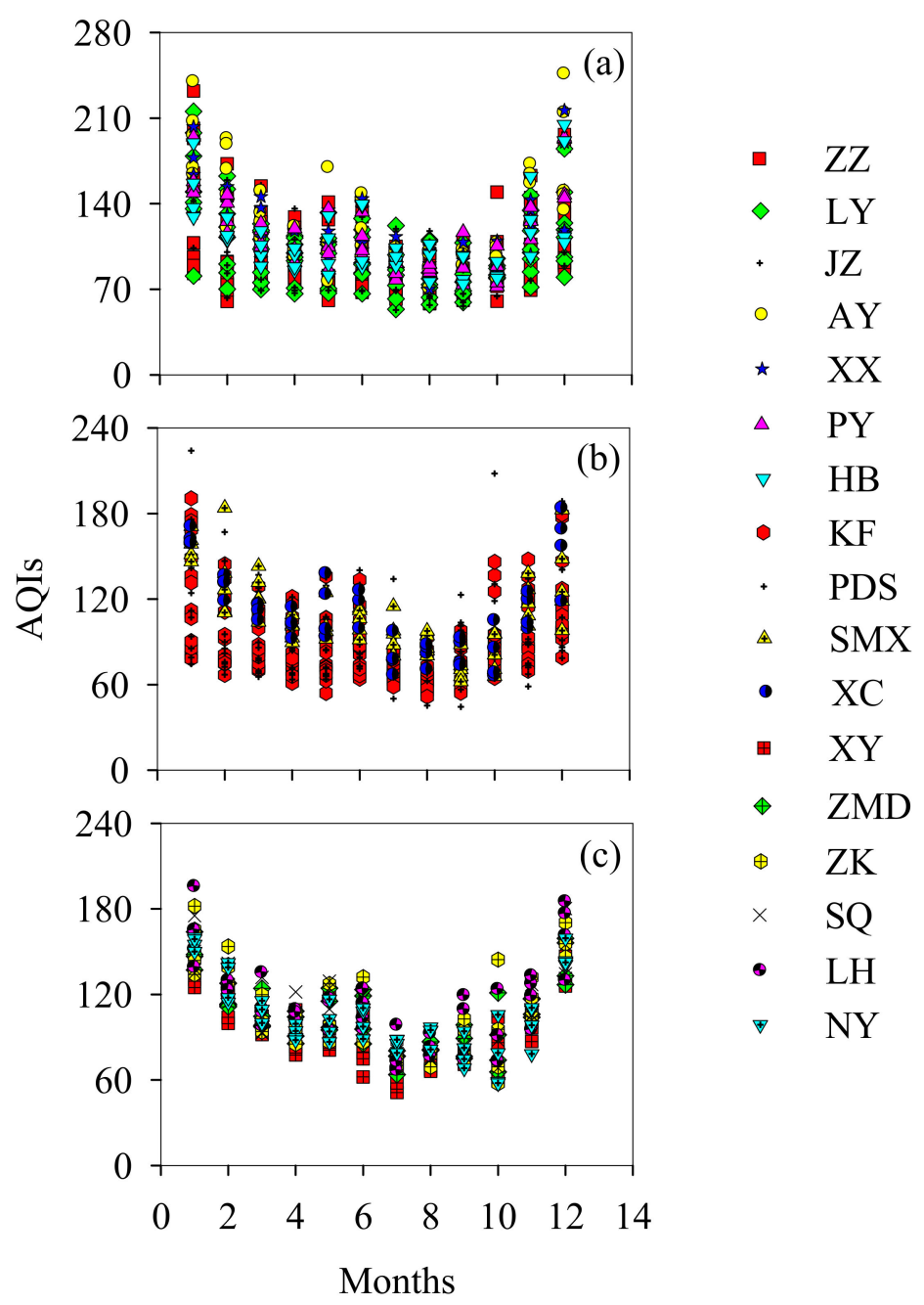

Figure 4. Multiyear seasonal changes of AQI values in municipalities of northwestern (a), central (b) and southeastern (c) Henan province, P. R., China (ZZ: Zhengzhou; LY: Luoyang; JZ: Jizozuo; AY:Anyang; XX: Xinxiang; PY: Puyang; HB: Hebi; KF: Kaifeng; PDS: Pingdingshan; SMX: Sanmenxia; XC: Xuchang; XY: Xinyang; ZMD: Zhumadian; ZK: Zhoukou; SQ: Shangqiu; LH: Luohe; NY: Nanyang).

The diurnal variations of AQI values for Zhengzhou, Kaifeng, Luoyang, Xinyang, Anyang, Pingdingshan, Zhumadian, and Jiaozuo in 2017 were analyzed in Figure 5. The bimodal tendency (a peak ranging from 8:00 a.m. to 10:00 a.m. and another peak ranging from 6:00 p.m. to 8:00 p.m.) was consistent with morning and evening traffic patterns, which indicated that traffic-related emissions were the most important pollutant source in Henan province. A significantly positive correlation between AQI values and vehicle numbers $(p<0.05)$ confirmed this inference. Furthermore, another peak around 2:00 p.m. to 4:00 p.m. in the summer represented a response to much higher $\mathrm{O}_{3}$ contents throughout the day. 

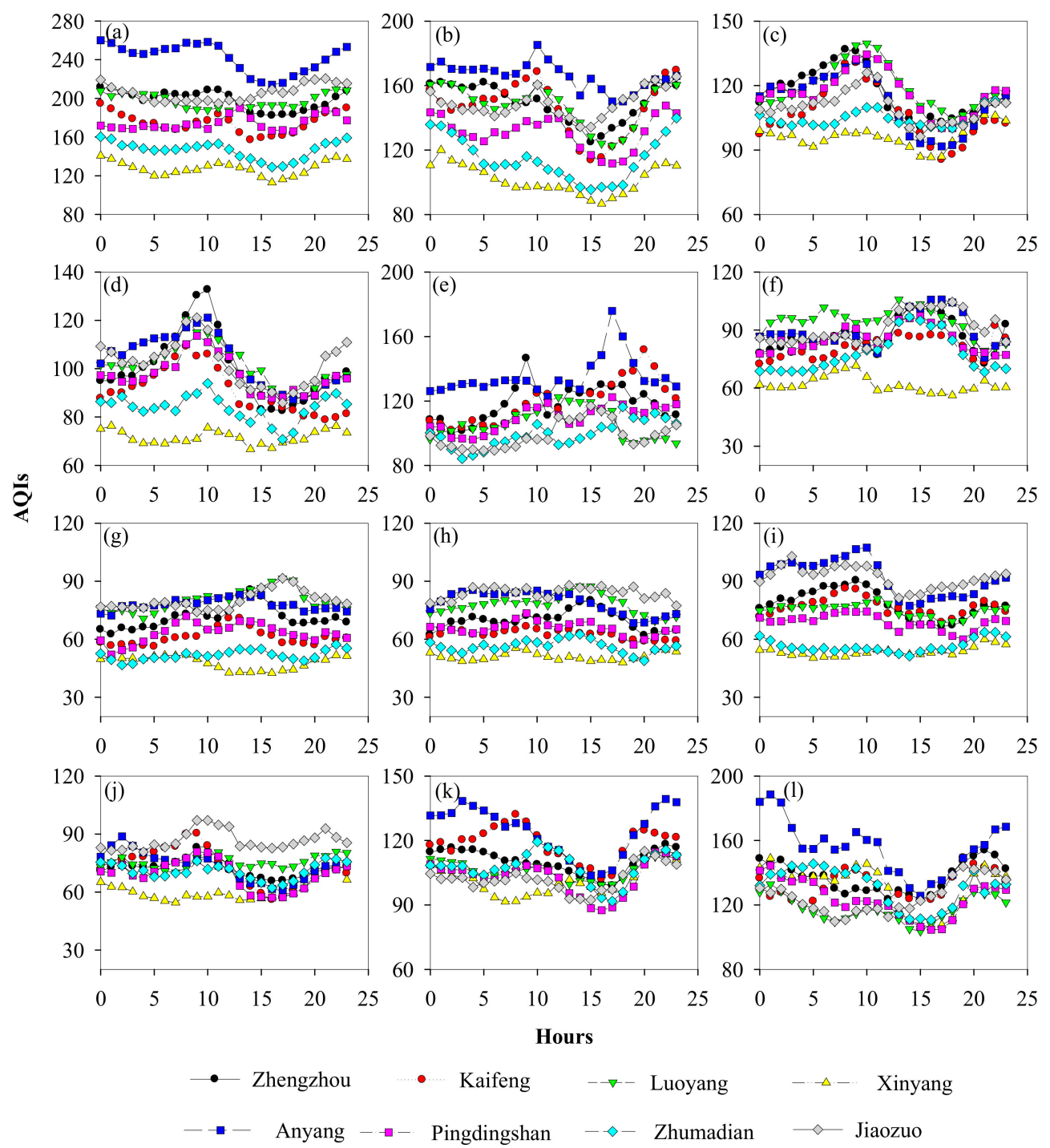

- Kaifeng $\quad-\rightarrow-$ Luoyang

Pingdingshan $\quad-\diamond-$ Zhumadian

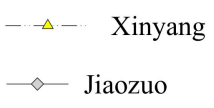

Figure 5. Diurnal changes of AQI values of Zhengzhou, Kaifeng, Luoyang, Xinyang, Anyang, Pingdingshan, Zhumadian, Jiaozuo in different months in 2017 ((a) January; (b) February; (c) March; (d) April; (e) May; (f) June; (g) July; (h) August; (i) September; (j) October; (k) November; (1) December).

\subsubsection{Air Pollutant Content Changes}

The multiyear changes for annual average mass concentrations of air pollutants $\left(\mathrm{SO}_{2}, \mathrm{NO}_{2}, \mathrm{PM}_{10}\right.$, $\mathrm{PM}_{2.5}, \mathrm{CO}$, and $\mathrm{O}_{3}-8 \mathrm{~h}$ ) in the 17 municipalities of Henan province are shown in Figure 6. Since the volume of industrial $\mathrm{SO}_{2}$ decreased significantly in past years (Table 2), the decreasing trends for annual average concentrations of $\mathrm{SO}_{2}$ were observed in the 17 municipalities of Henan province from 2006 to 2017, i.e., the annual average concentrations of $\mathrm{SO}_{2}$ in Zhengzhou, Kaifeng, Anyang, Pingdingshan, Jiaozuo, Sanmenxia, and Nanyang decreased from $0.069 \mathrm{mg} \cdot \mathrm{m}^{-3}, 0.054 \mathrm{mg} \cdot \mathrm{m}^{-3}$, $0.053 \mathrm{mg} \cdot \mathrm{m}^{-3}, 0.075 \mathrm{mg} \cdot \mathrm{m}^{-3}, 0.065 \mathrm{mg} \cdot \mathrm{m}^{-3}, 0.071 \mathrm{mg} \cdot \mathrm{m}^{-3}$, and $0.034 \mathrm{mg} \cdot \mathrm{m}^{-3}$ to $0.021 \mathrm{mg} \cdot \mathrm{m}^{-3}$, $0.020 \mathrm{mg} \cdot \mathrm{m}^{-3}, 0.031 \mathrm{mg} \cdot \mathrm{m}^{-3}, 0.024 \mathrm{mg} \cdot \mathrm{m}^{-3}, 0.025 \mathrm{mg} \cdot \mathrm{m}^{-3}, 0.021 \mathrm{mg} \cdot \mathrm{m}^{-3}$, and $0.015 \mathrm{mg} \cdot \mathrm{m}^{-3}$, respectively. Furthermore, the higher and higher ratios of $\mathrm{NO}_{2} / \mathrm{SO}_{2}$ in the municipalities of Henan province showed that vehicle emissions played a more crucial role in urban air pollution (Figure 7). 

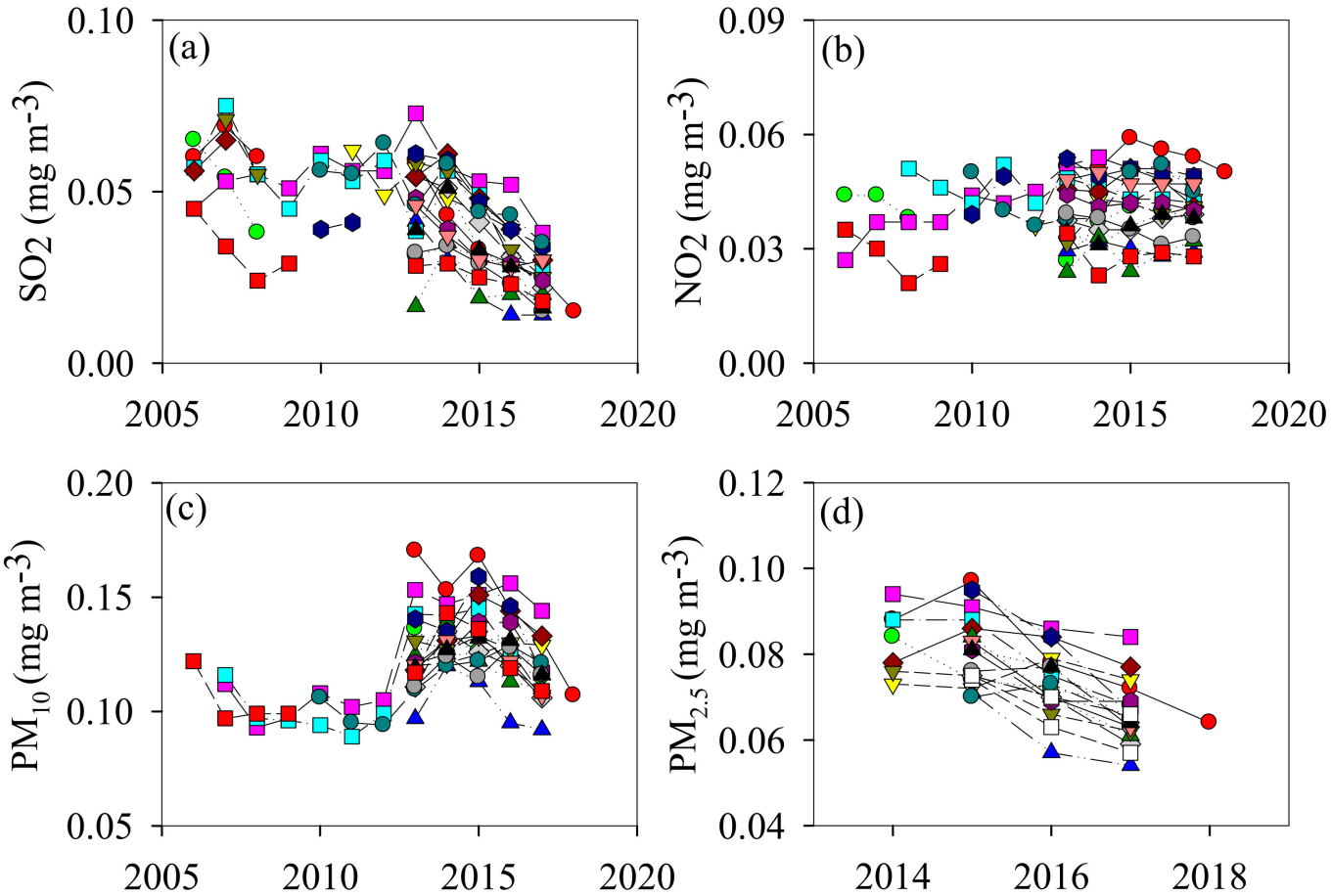

0.12
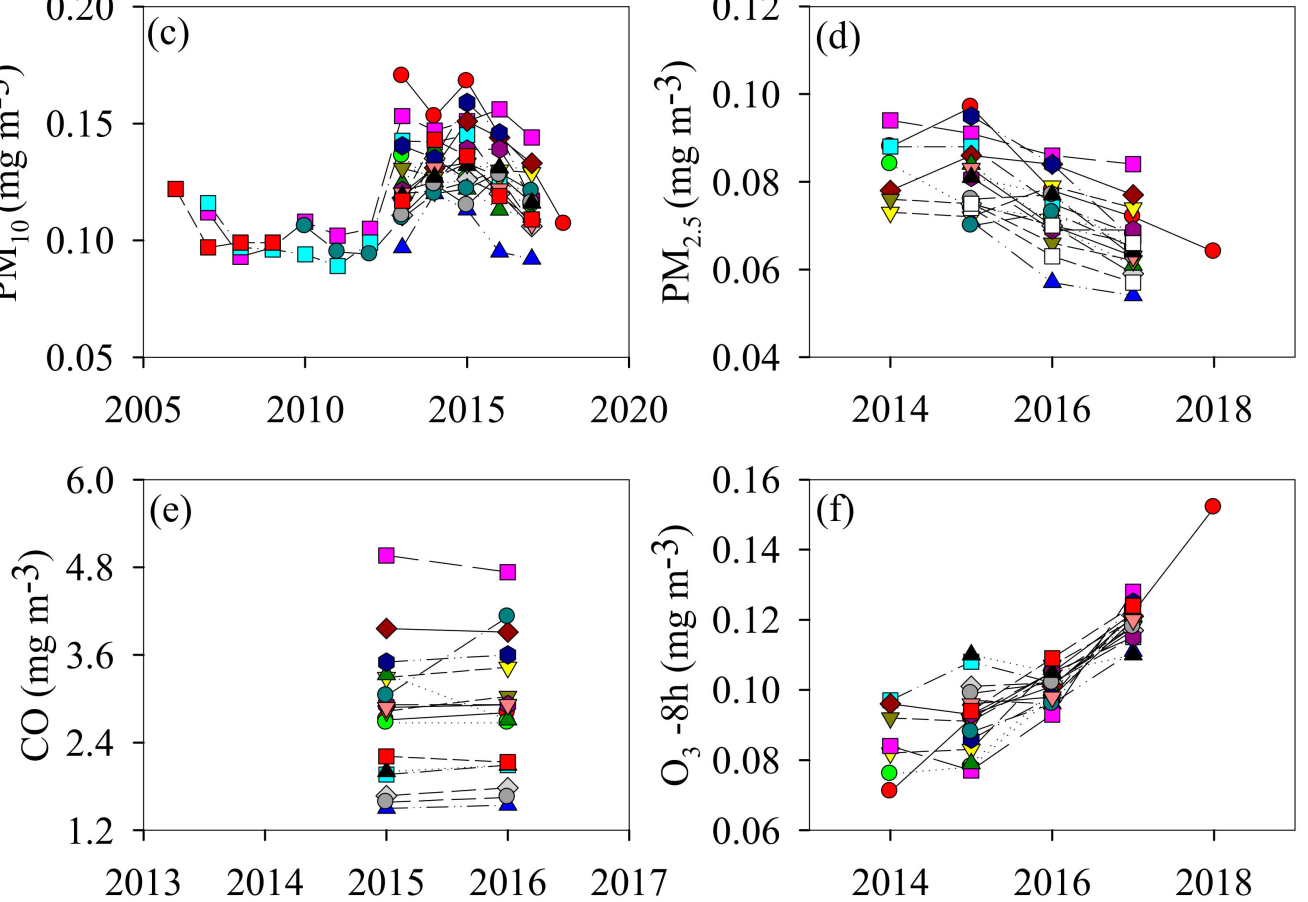

Year

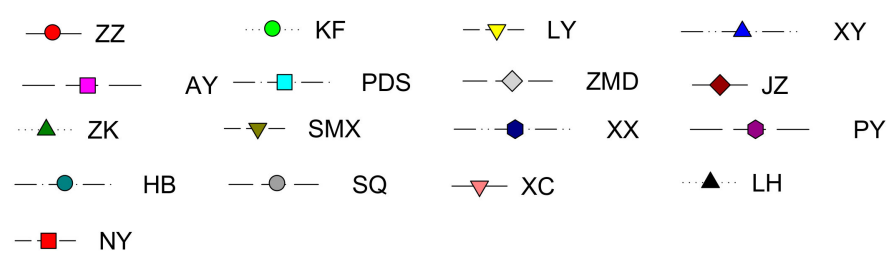

Figure 6. Multiyear change trends for annual average concentrations of $\mathrm{SO}_{2}(\mathbf{a}), \mathrm{NO}_{2}(\mathbf{b}), \mathrm{PM}_{10}$ (c), $\mathrm{PM}_{2.5}$ (d), $\mathrm{CO}(\mathbf{e})$, and $\mathrm{O}_{3}$ (f) in 17 municipalities of Henan province, P. R., China. (ZZ: Zhengzhou; KF: Kaifeng; LY: Luoyang; XY: Xinyang; AY:Anyang; PDS: Pingdingshan; ZMD: Zhumadian; JZ: Jizozuo; ZK: Zhoukou; SMX: Sanmenxia; XX: Xinxiang; PY: Puyang; HB: Hebi; SQ: Shangqiu; XC: Xuchang; LH: Luohe; NY: Nanyang). 
Table 2. The top five sources of industrial waste gas and $\mathrm{SO}_{2}$ in Henan Province from 2012 to 2017.

\begin{tabular}{|c|c|c|c|c|c|c|}
\hline $\begin{array}{c}\text { Volume of Industrial } \\
\text { Waste Gas (100 Million } \\
\text { Standard Cubic } \\
\text { Meters) }\end{array}$ & 2012 & 2013 & 2014 & 2015 & 2016 & 2017 \\
\hline Total & $35,001.92$ & $37,665.26$ & $39,628.66$ & $36,285.61$ & $29,810.21$ & $29,439.65$ \\
\hline $\begin{array}{c}\text { Power, Thermal } \\
\text { Production and Supply } \\
\text { Industries }\end{array}$ & $\begin{array}{l}13,445.68 \\
(38.41)\end{array}$ & $\begin{array}{c}14,817.16 \\
(39.34)\end{array}$ & $\begin{array}{c}14,841.43 \\
(37.45)\end{array}$ & $\begin{array}{c}11,837.79 \\
(32.62)\end{array}$ & $\begin{array}{c}10,006.85 \\
(33.57)\end{array}$ & $\begin{array}{c}10,566.39 \\
(35.89)\end{array}$ \\
\hline $\begin{array}{c}\text { Nonmetal Mineral } \\
\text { Production Industries }\end{array}$ & $\begin{array}{c}7482.00 \\
(21.38)\end{array}$ & $\begin{array}{c}7885.96 \\
(20.94)\end{array}$ & $\begin{array}{l}8570.87 \\
(21.63)\end{array}$ & $\begin{array}{c}10,109.15 \\
(27.86)\end{array}$ & $\begin{array}{l}7559.59 \\
(25.36)\end{array}$ & $\begin{array}{l}6344.11 \\
(21.55)\end{array}$ \\
\hline $\begin{array}{l}\text { Ferrous Metal Smelting } \\
\text { and Black Calendaring } \\
\text { Industries }\end{array}$ & $\begin{array}{l}4063.39 \\
(11.61)\end{array}$ & $\begin{array}{l}4569.84 \\
(12.13)\end{array}$ & $\begin{array}{l}5357.37 \\
(13.52)\end{array}$ & $\begin{array}{l}4883.51 \\
(13.46)\end{array}$ & $\begin{array}{l}4637.69 \\
(15.56)\end{array}$ & $\begin{array}{l}4223.69 \\
(14.35)\end{array}$ \\
\hline $\begin{array}{l}\text { Nonferrous Smelting } \\
\text { and Black Calendaring } \\
\text { Industries }\end{array}$ & $\begin{array}{l}4365.84 \\
(12.47)\end{array}$ & $\begin{array}{c}5239.53 \\
(13.91)\end{array}$ & $\begin{array}{l}4489.86 \\
(11.33)\end{array}$ & $\begin{array}{l}4022.70 \\
(11.09)\end{array}$ & $\begin{array}{c}3206.32 \\
(10.76)\end{array}$ & $\begin{array}{c}2845.83 \\
(9.67)\end{array}$ \\
\hline $\begin{array}{c}\text { Chemical Raw Material } \\
\text { and Chemical } \\
\text { Manufacturing } \\
\text { Industries }\end{array}$ & $\begin{array}{c}1614.61 \\
(4.61)\end{array}$ & $\begin{array}{c}1739.38 \\
(4.62)\end{array}$ & $\begin{array}{c}2496.46 \\
(6.30)\end{array}$ & $\begin{array}{l}2138.55 \\
(5.89)\end{array}$ & $\begin{array}{c}1555.15 \\
(5.22)\end{array}$ & $\begin{array}{l}1523.64 \\
(5.18)\end{array}$ \\
\hline $\begin{array}{l}\text { Volume of Industrial } \\
\qquad \mathrm{SO}_{2} \text { (Ton) }\end{array}$ & 2012 & 2013 & 2014 & 2015 & 2016 & 2017 \\
\hline Total & $1,034,059$ & $1,005,987$ & $939,405.28$ & $812,900.46$ & $238,963.27$ & $118,338.49$ \\
\hline $\begin{array}{c}\text { Power, Thermal } \\
\text { Production and Supply } \\
\text { Industries }\end{array}$ & $\begin{array}{l}415,686.71 \\
(40.20)\end{array}$ & $\begin{array}{l}372,197.38 \\
\quad(37.00)\end{array}$ & $\begin{array}{l}278,404.36 \\
(30.00)\end{array}$ & $\begin{array}{l}252,642.96 \\
(31.08)\end{array}$ & $\begin{array}{l}52,692.19 \\
(22.05)\end{array}$ & $\begin{array}{c}19,256.42 \\
(16.27)\end{array}$ \\
\hline $\begin{array}{c}\text { Nonmetal Mineral } \\
\text { Production Industries }\end{array}$ & $\begin{array}{c}152,370.40 \\
(14.74) \\
\end{array}$ & $\begin{array}{l}168,412.65 \\
(16.74)\end{array}$ & $\begin{array}{l}177,870.05 \\
(18.93)\end{array}$ & $\begin{array}{c}162,867.79 \\
(20.04)\end{array}$ & $\begin{array}{l}66,660.64 \\
(27.90)\end{array}$ & $\begin{array}{c}45,524.14 \\
(38.47)\end{array}$ \\
\hline $\begin{array}{c}\text { Ferrous Metal Smelting } \\
\text { and Black Calendaring } \\
\text { Industries }\end{array}$ & $\begin{array}{l}115,958.89 \\
(11.21)\end{array}$ & $\begin{array}{l}118,223.63 \\
(11.75)\end{array}$ & $\begin{array}{l}136,168.84 \\
(14.50)\end{array}$ & $\begin{array}{l}88,880.45 \\
(10.93)\end{array}$ & $\begin{array}{l}39,136.35 \\
(16.38)\end{array}$ & $\begin{array}{c}15,856.89 \\
(13.40)\end{array}$ \\
\hline $\begin{array}{c}\text { Nonferrous Smelting } \\
\text { and Black Calendaring } \\
\text { Industries }\end{array}$ & $\begin{array}{l}80,440.65 \\
\quad(7.78)\end{array}$ & $\begin{array}{l}83,632.04 \\
(8.31)\end{array}$ & $\begin{array}{l}85,156.75 \\
\quad(9.06)\end{array}$ & $\begin{array}{l}66,328.19 \\
(8.16)\end{array}$ & $\begin{array}{c}32,200.38 \\
(13.48)\end{array}$ & $\begin{array}{c}22,751.38 \\
(19.23)\end{array}$ \\
\hline $\begin{array}{c}\text { Chemical Raw Material } \\
\text { and Chemical } \\
\text { Manufacturing } \\
\text { Industries }\end{array}$ & $\begin{array}{c}82,144.84 \\
(7.94)\end{array}$ & $\begin{array}{c}89,088.13 \\
(8.86)\end{array}$ & $\begin{array}{c}95,879.91 \\
(20.21)\end{array}$ & $\begin{array}{c}104,624.11 \\
(12.87)\end{array}$ & $\begin{array}{c}16,340.59 \\
(0.84)\end{array}$ & $\begin{array}{c}6,844.63 \\
(5.78)\end{array}$ \\
\hline
\end{tabular}

Table 3 summarizes the annual averages and standard deviations of annual population-weighted average (PWA) concentrations of the six air pollutants in Henan province for 2013-2017. In 2015 $(2016,2017)$, the annual PWA values were $0.0344(0.0294,0.0200) \mathrm{mg} \mathrm{m}^{-3}$ for $\mathrm{SO}_{2}, 0.0403(0.0405$, $0.0402) \mathrm{mg} \mathrm{m}^{-3}$ for $\mathrm{NO}_{2}, 0.135(0.127,0.117) \mathrm{mg} \mathrm{m}^{-3}$ for $\mathrm{PM}_{10}, 0.081(0.073,0.066) \mathrm{mg} \mathrm{m}^{-3}$ for $\mathrm{PM}_{2.5}$, $2.690(2.687,2.320) \mathrm{mg} \mathrm{m}^{-3}$ for $\mathrm{CO}$, and $0.150(0.165,0.183) \mathrm{mg} \mathrm{m}^{-3}$ for $\mathrm{O}_{3}-8 \mathrm{~h}$, respectively, which were much higher than those of the whole country reported by Song et al. (2017) [9]. Among these, the PWA values of $\mathrm{NO}_{2}, \mathrm{PM}_{10}, \mathrm{PM}_{2.5}$ and $\mathrm{O}_{3}-8$ h were relatively higher than the CAAQs Grade II. $\mathrm{PM}_{2.5}$ and $\mathrm{PM}_{10}$ were the major pollutants as their PWA values were always much higher than the CAAQs Grade II and correlated to the corresponding AQI and R values $(p<0.05)$ in Henan province. The $\mathrm{NO}_{2}$ PWA values were always higher than the CAAQs Grade II in Henan province in 2013 to 2017. Even worse, there was a linear increase in the $\mathrm{O}_{3}-8 \mathrm{~h}$ contents from 2013 to 2017, which aggravated the air pollution situation in Henan province. 

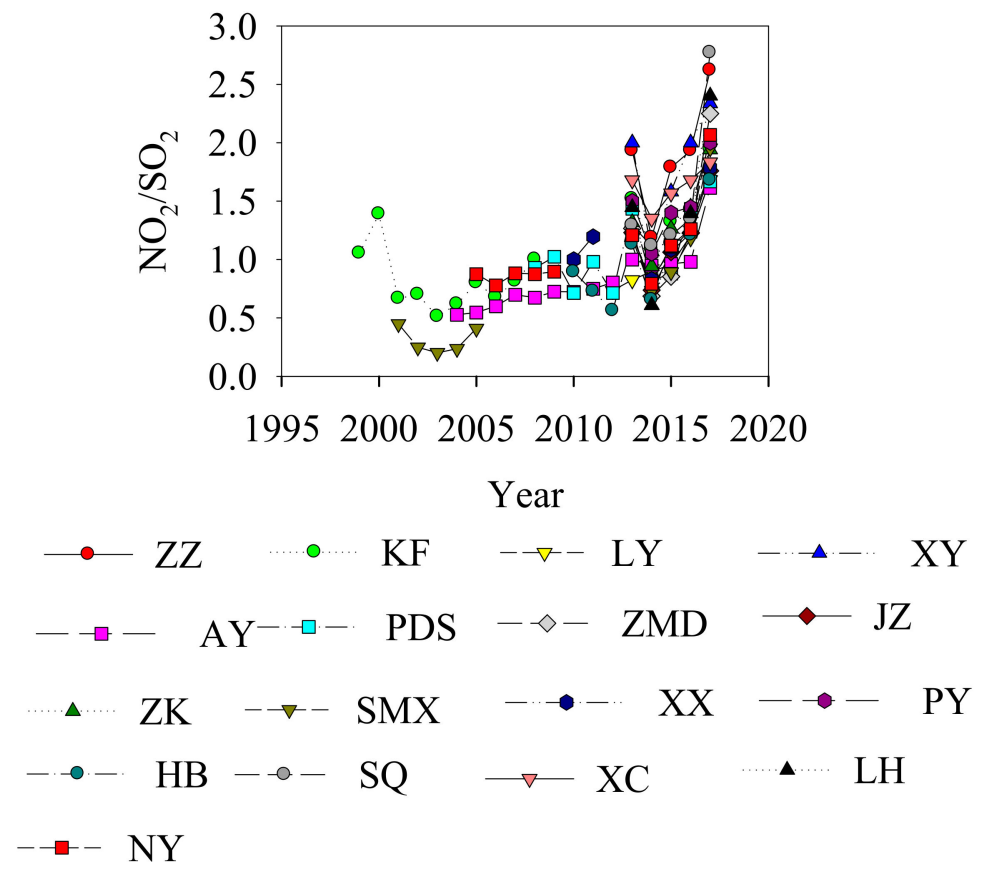

Figure 7. Multiyear changes of ratios for $\mathrm{NO}_{2} / \mathrm{SO}_{2}$ in the 17 municipalities of Henan province. (ZZ: Zhengzhou; KF: Kaifeng; LY: Luoyang; XY: Xinyang; AY:Anyang; PDS: Pingdingshan; ZMD: Zhumadian; JZ: Jizozuo; ZK: Zhoukou; SMX: Sanmenxia; XX: Xinxiang; PY: Puyang; HB: Hebi; SQ: Shangqiu; XC: Xuchang; LH: Luohe; NY: Nanyang).

Table 3. Annual average population-weighted average (PWA) and related standards for six air pollutants in Henan provinces during 2013-2017.

\begin{tabular}{cccccccc}
\hline \multicolumn{1}{c}{$\mathbf{C}$ Year } & $\mathbf{C}$ & $\mathbf{S O}_{\mathbf{2}}$ & $\mathbf{N O}_{\mathbf{2}}$ & $\mathbf{P M}_{\mathbf{1 0}}$ & $\mathbf{P M}_{\mathbf{2 . 5}}$ & $\mathbf{C O}$ & $\mathbf{O}_{\mathbf{3}}$ \\
\hline & & 0.044 & 0.0405 & 0.127 & - & - & - \\
2013 & 0.043 & 0.0397 & 0.134 & - & - & - \\
2014 & 0.034 & 0.0403 & 0.135 & 0.081 & 2.690 & 0.150 \\
2016 & 0.029 & 0.0405 & 0.127 & 0.073 & 2.687 & 0.165 \\
2017 & 0.020 & 0.0402 & 0.117 & 0.066 & 2.320 & 0.183 \\
GB3095-2012 Grade & 0.060 & 0.040 & 0.070 & 0.035 & 4 & 0.160 \\
\hline
\end{tabular}

—: There was no result reported. C: Annual average population-weighted average concentrations for six air pollutants in Henan provinces during 2013-2017.

\subsection{Spatial Characteristics of Air Pollution}

Figure 8 shows the spatial distributions of annual average AQI values, $R$ values, and exceeding standards days (AQI $>100$ ) in Henan province in 2015-2017. Significant regional differences in urban air quality were observed in Henan province $(p<0.05)$. Actually, the statistical results indicated that the annual average AQI values in the 17 municipalities were all higher than 100 except Xinyang, with the values decreasing from northwest to southeast. Meanwhile, northwest-southeast decreasing trends for $R$ values and exceeding standard days were also found in Henan province. In 2017, the annual average AQI values (R values, exceeding standard days) in Anyang, Hebi, Puyang, Jiaozuo, Xinxiang, Luoyang, Zhengzhou, and Kaifeng were 131.85 (1.40, 209), 112.77 (1.11, 177), 114.8 (1.14, 181), $121.12(1.24,190)$, $114.65(1.18,190), 119.69(1.22,195), 119.97(1.25,198)$, and $111.36(1.09,175)$, respectively, while the annual average AQI values (exceeding standard days) in Nanyang, Xinyang, and Zhumadian were $103.92(0.97,160), 89.23(0.70,98)$, and $103.22(0.94,146)$, respectively. Too-rapid urban development, an irrational economic structure, and the malformation of the energy consumption structure caused relatively poorer air quality in the northwest, and a run of foggy, hazy days caused a decline in visibility, 
traffic obstacles, a rise in urban fires (Figure 9), an increase in diseases (including cancer, respiratory disorders, heart disease, and nervous system disorders; see Figure 10) and psychological disorders, which thus caused an explosion of integrated risk in the 17 municipalities of Henan province from 2015 to 2017.

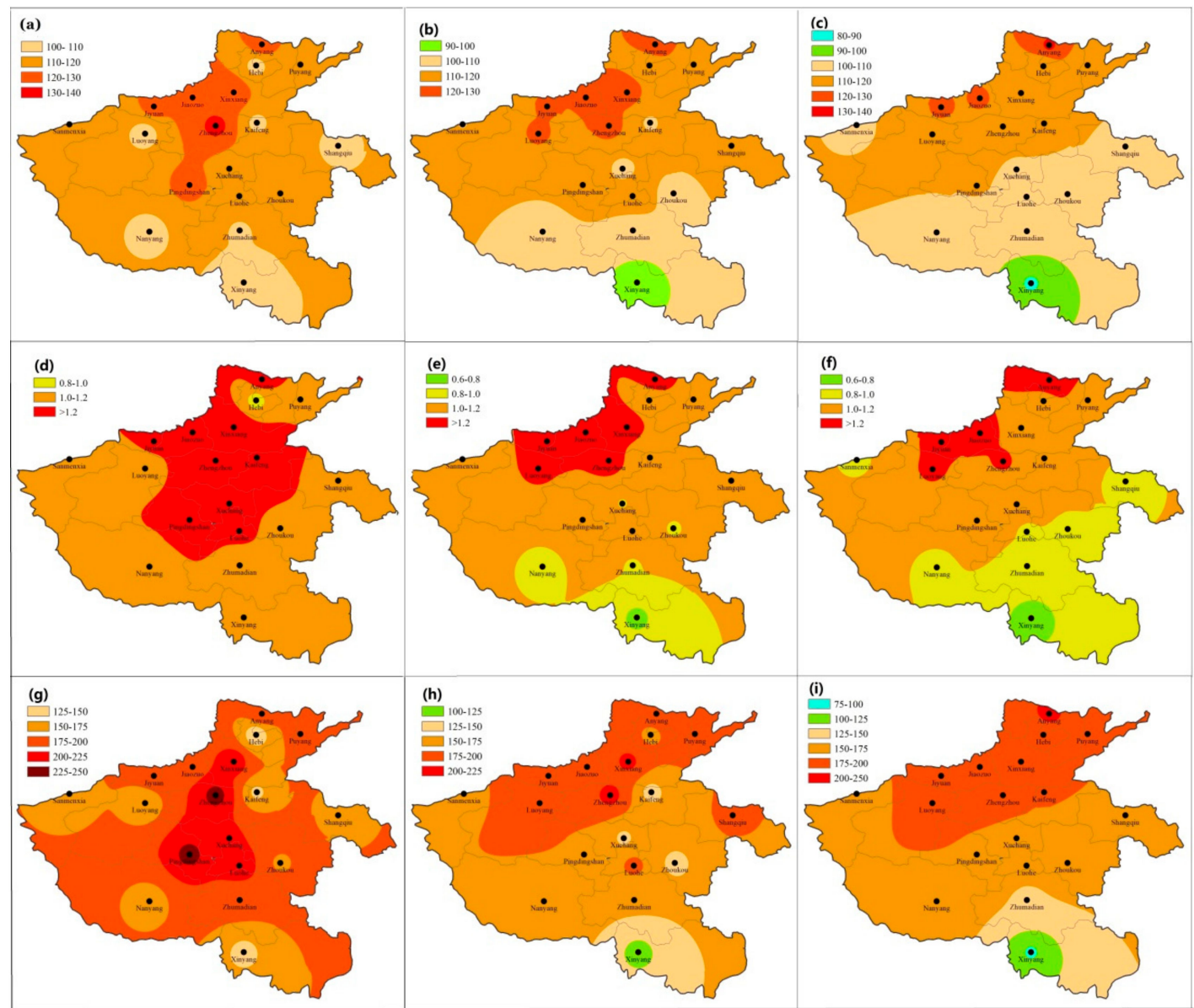

Figure 8. Spatial distributions of average annual air quality during 2015-2017 ((a-c): AQI values in 2015, 2016 and 2017, respectively; (d-f): R values in 2015, 2016, and 2017, respectively; (g-i): Exceeding-standard (AQI > 100) days in 2015, 2016, and 2017, respectively). 

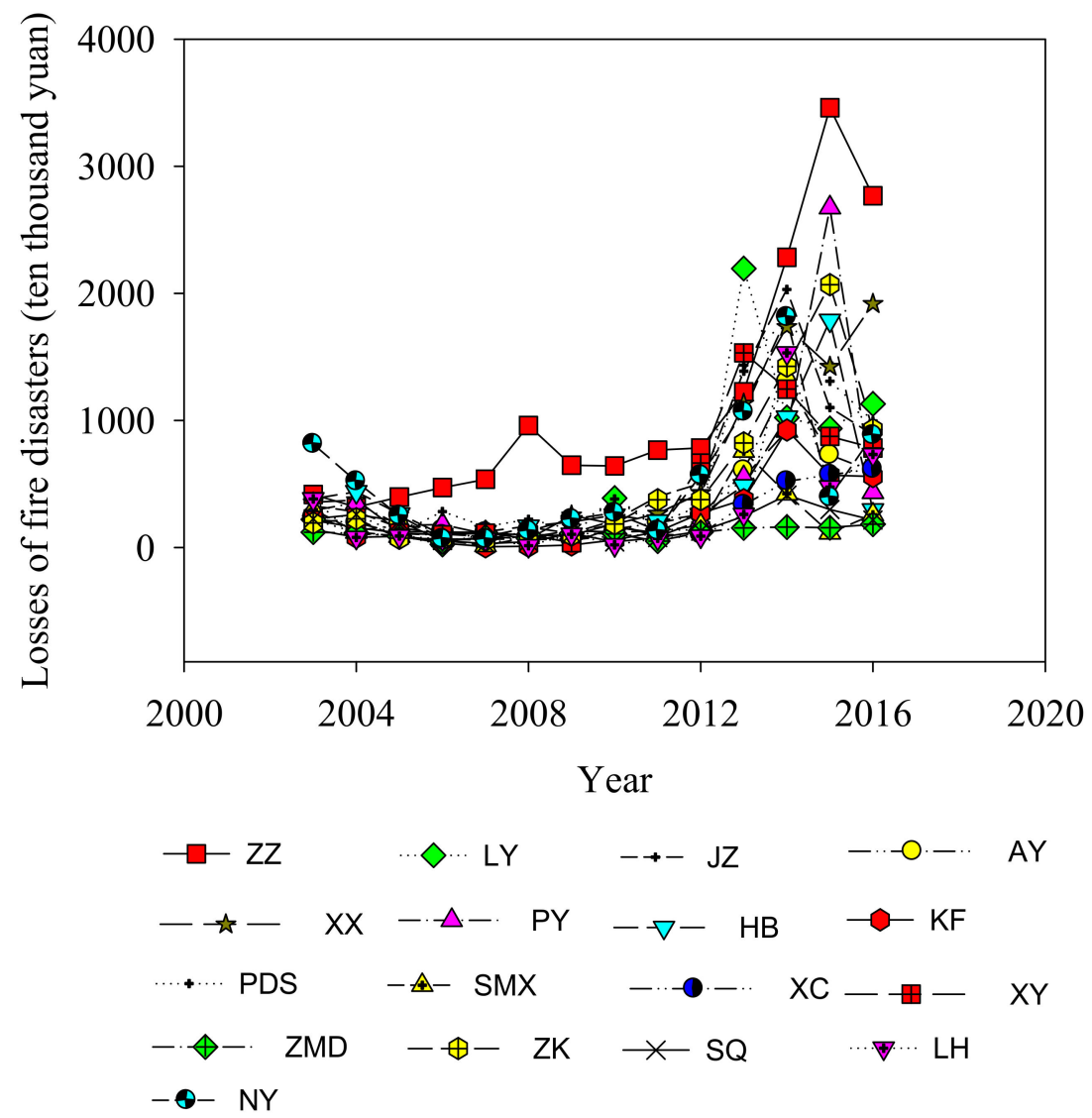

Figure 9. Losses of fire disasters in 17 municipalities of Henan province, P. R., China. (ZZ: Zhengzhou; LY: Luoyang; JZ: Jizozuo; AY:Anyang; XX: Xinxiang; PY: Puyang; HB: Hebi; KF: Kaifeng; PDS: Pingdingshan; SMX: Sanmenxia; XC: Xuchang; XY: Xinyang; ZMD: Zhumadian; ZK: Zhoukou; SQ: Shangqiu; LH: Luohe; NY: Nanyang).

Significant spatial differences in the annual average concentrations of six air pollutants $\left(\mathrm{SO}_{2}, \mathrm{NO}_{2}\right.$, $\mathrm{PM}_{10}, \mathrm{PM}_{2.5}, \mathrm{CO}$, and $\mathrm{O}_{3}-8 \mathrm{~h}$ ) were observed among the 17 municipalities of Henan province (Figure 6). In $2015(2016,2017)$, the annual average values in Henan province were $0.037 \pm 0.011(0.031 \pm 0.009$, $0.021 \pm 0.006) \mathrm{mg} \cdot \mathrm{m}^{-3}$ for $\mathrm{SO}_{2}, 0.042 \pm 0.009(0.042 \pm 0.009,0.041 \pm 0.007) \mathrm{mg} \cdot \mathrm{m}^{-3}$ for $\mathrm{NO}_{2}, 0.135 \pm 0.015$ $(0.129 \pm 0.014,0.117 \pm 0.012) \mathrm{mg} \cdot \mathrm{m}^{-3}$ for $\mathrm{PM}_{10}, 0.081 \pm 0.008(0.074 \pm 0.008,0.066 \pm 0.007) \mathrm{mg} \cdot \mathrm{m}^{-3}$ for $\mathrm{PM}_{2.5}, 2.765 \pm 0.910(2.831 \pm 0.909,2.402 \pm 0.758) \mathrm{mg} \cdot \mathrm{m}^{-3}$ for $\mathrm{CO}$, and $0.151 \pm 0.015(0.164 \pm 0.011$, $0.184 \pm 0.017) \mathrm{mg} \cdot \mathrm{m}^{-3}$ for $\mathrm{O}_{3}-8 \mathrm{~h}$, respectively. Furthermore, the annual average concentrations of these six air pollutants in $2016(2017)$ were $0.037(0.025) \mathrm{mg} \cdot \mathrm{m}^{-3}, 0.048(0.046) \mathrm{mg} \cdot \mathrm{m}^{-3}, 0.139(0.126) \mathrm{mg} \cdot \mathrm{m}^{-3}$, $0.078(0.072) \mathrm{mg} \cdot \mathrm{m}^{-3}, 3.524(2.93) \mathrm{mg} \cdot \mathrm{m}^{-3}$, and $0.168(0.199) \mathrm{mg} \cdot \mathrm{m}^{-3}$, respectively, in the northwest, which were much higher than those in the southeast (where the values were $0.023(0.014) \mathrm{mg} \cdot \mathrm{m}^{-3}$, $0.032(0.032) \mathrm{mg} \cdot \mathrm{m}^{-3}, 0.111(0.102) \mathrm{mg} \cdot \mathrm{m}^{-3}, 0.063(0.057) \mathrm{mg} \cdot \mathrm{m}^{-3}, 1.817(1.723) \mathrm{mg} \cdot \mathrm{m}^{-3}$, and 0.160 $(0.166) \mathrm{mg} \cdot \mathrm{m}^{-3}$, respectively). The characteristics of the iron and steel industries, which have high sulfur content in their feed materials and consume a large volume of coal, more extensive economic growth, and a high population density in northwestern Henan province, caused the relatively higher air pollutant concentrations, which was consistent with the results of 2012 discussed by Liu et al. (2018) [1]. 

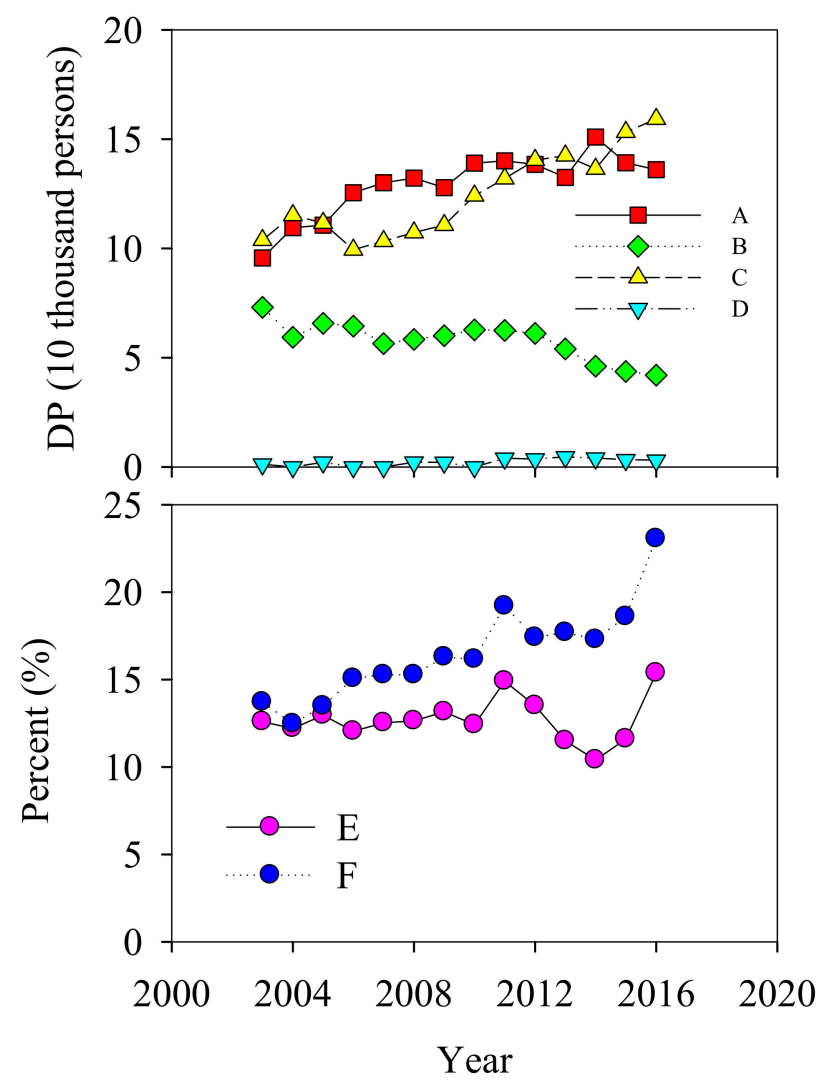

Figure 10. The effects of air pollution on residents' health. (a): The Death populations of cancer A, respiratory diseases $B$, heart disease $C$, nervous system diseases $D$ in Henan province throughout a year; (b): The ratios of respiratory inpatients in the Health-Department-Hospital for municipality level $\mathrm{E}$ and county level $\mathrm{F}$ in Henan province, respectively.

\subsection{Correlations Between Air Pollution and Socioeconomic Influence Factors}

The urbanization rate, GDP, per capita GDP, urban population scale, and vehicle numbers were applied for evaluating the urban development and population growth (UDPG) levels in Henan province, because they are representatives of UDPG and closely correlated to the air quality (AQI values) in the 17 municipalities (Table $4, p<0.01$ ). Among these UDPG factors, urban population, urbanization rate, GDP, per capita GDP, and vehicle numbers were significantly positively correlated with AQI values $(p<0.01)$, with the correlation coefficients being $0.437,0.316,0.399,0.556$, and 0.484 , respectively.

The decline in air quality in the 17 municipalities of Henan province (Figure 2) was closely correlated to the unique economic growth and change of industrial structure (EGCIS) and its change trends. The 10 EGCIS influence factors, including GDP, $E G_{2}, E G_{3}, E G_{4}, E G_{5}, E G_{6}, E G_{7}, E G_{2} / G D P$, $E G_{3} / G D P$ and $E G_{4} / G D P$, were chosen to evaluate the EGCIS values in Henan province. Obviously, it was the synchronous increase of GDP, primary industry, secondary industry, tertiary industry, industry, construction, and the ratios of tertiary industry that led to the change trends for AQI values, since there were significantly positive correlations between these EGCIS influence factors and AQI values $(p<0.05$, Table 5). Among these factors, tertiary industry was the most correlated factor, followed by primary industry and secondary industry, the corresponding correlation coefficients of which were $0.698,0.402$, and 0.409 , respectively (Table 5). 
Table 4. Correlations between AQI and urban development and population growth (UDPG) influence factors.

\begin{tabular}{ccccccc}
\hline Items & AQI & BYL & Urban Populations & Urbanization & GDP & PCGDP \\
\hline AQI & 1 & & & & & \\
BYL & $0.484^{* *}$ & 1 & 1 & & & \\
Urban populations & $0.437^{* *}$ & $0.749^{* *}$ & $0.821^{* *}$ & 1 & $0.307^{* *}$ & 1 \\
Urbanization & $0.316^{* *}$ & $0.757^{* *}$ & $0.452^{* *}$ & $0.697^{* *}$ & $0.591^{* *}$ & 1 \\
GDP & $0.399^{* *}$ & $0.418^{* *}$ & $0.644^{* *}$ & &
\end{tabular}

Table 5. Correlations between AQI and economic growth and change of industrial structure (EGCIS)-related influence factors in the 17 municipalities of Henan province during 2003 to 2017.

\begin{tabular}{|c|c|c|c|c|c|c|c|c|c|c|c|}
\hline Items & AQI & $\mathrm{EG}_{1}$ & $\mathrm{EG}_{2}$ & $\mathrm{EG}_{3}$ & $\mathrm{EG}_{4}$ & $\mathrm{EG}_{5}$ & $\mathrm{EG}_{6}$ & $\mathrm{EG}_{7}$ & $\mathrm{EG}_{8}$ & $\mathrm{EG}_{9}$ & $\mathrm{EG}_{10}$ \\
\hline AQI & 1 & & & & & & & & & & \\
\hline $\mathrm{EG}_{1}$ & $0.399^{* *}$ & 1 & & & & & & & & & \\
\hline $\mathrm{EG}_{3}$ & $0.409^{* *}$ & $0.873^{* *}$ & $0.586^{* *}$ & 1 & & & & & & & \\
\hline $\mathrm{EG}_{4}$ & $0.698^{* *}$ & $0.606^{* *}$ & $0.632 * *$ & $0.660^{* *}$ & 1 & & & & & & \\
\hline $\mathrm{EG}_{5}$ & $0.447^{* *}$ & $0.618^{* *}$ & $0.685^{* *}$ & $0.899^{* *}$ & $0.723^{* *}$ & 1 & & & & & \\
\hline $\mathrm{EG}_{8}$ & $-0.447^{* *}$ & $-0.592 * *$ & -0.204 * & $-0.715^{* *}$ & $-0.722 * *$ & $-0.722^{* *}$ & $-0.662 *$ & -0.132 & 1 & & \\
\hline $\mathrm{EG}_{9}$ & $-0.523^{* *}$ & -0.126 & -0.182 & 0.145 & $-0.521 * *$ & 0.132 & $-0.372^{* *}$ & -0.032 & 0.094 & 1 & \\
\hline $\mathrm{EG}_{10}$ & $0.592^{* *}$ & $0.303^{* *}$ & $0.303^{* *}$ & 0.177 & $0.788^{* *}$ & 0.194 & $0.632 * *$ & 0.070 & $-0.413^{* *}$ & $-0.779 * *$ & 1 \\
\hline
\end{tabular}

$\mathrm{EG}_{1}$ : GDP; $\mathrm{EG}_{2}$ : Primary industry; $\mathrm{EG}_{3}$ : Secondary industry; $\mathrm{EG}_{4}$ : Tertiary industry; $\mathrm{EG}_{5}$ : Industry; $\mathrm{EG}_{6}$ : Construction; $\mathrm{EG}_{7}$ : Tourism; $\mathrm{EG}_{8}$ : Ratios forEG $/ \mathrm{EG}_{1}$; $\mathrm{EG}_{9}$ : Ratios for $\mathrm{EG}_{3} / \mathrm{EG}_{1}$; $\mathrm{EG}_{10}$ : Ratios for $\mathrm{EG} 4 / \mathrm{EG} 1$; Note: $*: p<0.05 ; * *: p<0.01$.

The values of $E S_{1}, E S_{2}, E S_{3}, E S_{4}, E S_{5}, E S_{6}, E S_{7}, E S_{2} / E S_{1}, E S_{3} / E S_{1}, E S_{5} / E S_{4}, E S_{6} / E S_{4}$, and $E S_{7} / E S_{4}$ affected the EGCIS levels to great extents. Among which, significantly positive correlations between AQI values and total energy consumption were observed in 2003 to $2017(p<0.05)$. Obviously, Table 6 showed that energy production (including coal production) decreased greatly in recent years, while energy consumption, especially coal consumption, increased year by year in Henan province. Furthermore, air pollution levels were significantly positively correlated to energy consumption growth and structure change potential (ECGSC) parameters, such as the living energy consumption, living power consumption, heat consumption of large-scale enterprises, power consumption of large-scale enterprises, and proportion rates for $\mathrm{ES}_{3} / \mathrm{ES}_{1}, \mathrm{ES}_{6} / \mathrm{ES}_{4}$, and $\mathrm{ES}_{7} / \mathrm{ES}_{4}$ (Table 7). 
Table 6. The energy production and consumption in Henan province from 2003 to 2017.

\begin{tabular}{|c|c|c|c|c|c|c|c|c|c|c|}
\hline \multirow{2}{*}{ Year } & \multicolumn{5}{|c|}{ Energy Production } & \multicolumn{5}{|c|}{ Energy Consumption } \\
\hline & $\begin{array}{c}\mathbf{E P}_{\mathbf{t}}(\mathbf{1 0 , 0 0 0} \\
\text { Tons of SCE) }\end{array}$ & $\begin{array}{l}\mathrm{EP}_{1} \\
(\%)\end{array}$ & $\begin{array}{l}\mathrm{EP}_{2} \\
(\%)\end{array}$ & $\begin{array}{l}\mathrm{EP}_{3} \\
(\%)\end{array}$ & $\begin{array}{l}\mathrm{EP}_{4} \\
(\%)\end{array}$ & $\begin{array}{c}E^{E}(10,000 \\
\text { Tons of SCE) }\end{array}$ & $\begin{array}{l}\mathrm{EC}_{1} \\
(\%)\end{array}$ & $\begin{array}{l}\mathrm{EC}_{2} \\
(\%)\end{array}$ & $\begin{array}{l}\mathrm{EC}_{3} \\
(\%)\end{array}$ & $\begin{array}{l}\mathrm{EC}_{4} \\
(\%)\end{array}$ \\
\hline 2003 & 10,634 & 88.3 & 7.4 & 2.3 & 2.0 & 10,595 & 86.7 & 9.4 & 1.9 & 2.0 \\
\hline 2004 & 13,079 & 90.4 & 5.7 & 1.7 & 2.2 & 13,074 & 86.6 & 9.2 & 2.0 & 2.2 \\
\hline 2005 & 14,522 & 91.3 & 5.0 & 1.8 & 1.9 & 14,625 & 87.2 & 8.7 & 2.2 & 1.9 \\
\hline 2006 & 15,002 & 91.7 & 4.7 & 1.7 & 2.0 & 16,234 & 87.4 & 8.0 & 2.5 & 2.1 \\
\hline 2007 & 14,604 & 91.8 & 4.8 & 1.4 & 2.0 & 17,838 & 87.7 & 7.9 & 2.5 & 1.9 \\
\hline 2008 & 15,487 & 92.6 & 4.4 & 1.2 & 1.8 & 18,976 & 87.2 & 8.0 & 2.6 & 2.2 \\
\hline 2009 & 17,002 & 93.4 & 4.0 & 0.8 & 1.8 & 19,751 & 87.0 & 7.9 & 2.8 & 2.3 \\
\hline 2010 & 17,438 & 92.4 & 4.1 & 0.5 & 3.0 & 18,594 & 82.8 & 9.3 & 3.4 & 4.5 \\
\hline 2011 & 15,786 & 91.3 & 4.4 & 0.4 & 3.9 & 20,462 & 81.6 & 10.4 & 3.6 & 4.4 \\
\hline 2012 & 12,224 & 90.2 & 5.6 & 0.5 & 3.7 & 20,920 & 80.0 & 11.5 & 4.7 & 3.8 \\
\hline 2013 & 13,133 & 90.6 & 5.2 & 0.5 & 3.7 & 21,909 & 77.2 & 12.9 & 4.8 & 5.2 \\
\hline 2014 & 11,796 & 89.8 & 5.7 & 0.6 & 3.9 & 22,890 & 77.7 & 12.6 & 4.5 & 5.3 \\
\hline 2015 & 11,231 & 89.3 & 5.2 & 0.5 & 5.0 & 23,161 & 76.5 & 13.1 & 4.5 & 5.9 \\
\hline 2016 & 9705 & 88.9 & 4.6 & 0.5 & 6.0 & 23,117 & 75.1 & 13.5 & 5.2 & 6.2 \\
\hline 2017 & 10,091 & 88.6 & 4.0 & 0.4 & 7.0 & 22,944 & 73.3 & 14.1 & 5.9 & 6.8 \\
\hline
\end{tabular}

$\mathrm{EP}_{\mathrm{t}}$ : The total production of energy; $\mathrm{EP}_{1}$ : The ratios of coal production in the $\mathrm{EP}_{\mathrm{t}} ; \mathrm{EP}_{2}$ : The ratios of crude oil in the $\mathrm{EP}_{\mathrm{t}} ; \mathrm{EP}_{3}$ : The ratios of natural gas in the $\mathrm{EP}_{\mathrm{t}} ; \mathrm{EP}_{4}$ : The ratios of electricity in the $\mathrm{EP}_{\mathrm{t}} ; \mathrm{EC}_{\mathrm{t}}$ : The total consumption of energy; $\mathrm{EC}_{1}$ : The ratios of coal consumption in the $\mathrm{EC}_{\mathrm{t}} ; \mathrm{EC}_{2}$ : The ratios of crude oil consumption in the $\mathrm{EC}_{\mathrm{t}} ; \mathrm{EC}_{3}$ : The ratios of natural gas consumption in the $\mathrm{EC}_{\mathrm{t}} ; \mathrm{EC}_{4}$ : The ratios of electricity consumption in the $\mathrm{EC}_{\mathrm{t}}$.

Table 7. Correlations between AQI values and energy consumption growth and structure change potential (ECGSC) influence factors in 17 municipalities of Henan province from 2003 to 2017.

\begin{tabular}{|c|c|c|c|c|c|c|c|c|c|c|c|c|c|}
\hline Items & AQI & $\mathrm{ES}_{1}$ & $\mathrm{ES}_{2}$ & $\mathrm{ES}_{3}$ & $\mathrm{ES}_{4}$ & $\mathrm{ES}_{5}$ & $\mathrm{ES}_{6}$ & $\mathrm{ES}_{7}$ & $\mathrm{ES}_{8}$ & $\mathrm{ES}_{9}$ & $\mathrm{ES}_{10}$ & $\mathrm{ES}_{11}$ & $\mathrm{ES}_{12}$ \\
\hline AQI & 1 & & & & & & & & & & & & \\
\hline $\mathrm{ES}_{1}$ & 0.620 ** & 1 & & & & & & & & & & & \\
\hline $\mathrm{ES}_{2}$ & $-0.424 * *$ & $-0.522 * *$ & 1 & & & & & & & & & & \\
\hline $\mathrm{ES}_{3}$ & $0.578^{* *}$ & $0.971 * *$ & $-0.649 * *$ & 1 & & & & & & & & & \\
\hline $\mathrm{ES}_{4}$ & -0.032 & -0.071 & -0.102 & -0.011 & 1 & & & & & & & & \\
\hline $\mathrm{ES}_{5}$ & 0.015 & 0.145 & -0.088 & 0.207 & $0.684^{* *}$ & 1 & & & & & & & \\
\hline $\mathrm{ES}_{6}$ & $0.300 * *$ & 0.044 & -0.180 & 0.061 & $0.291 * *$ & 0.031 & 1 & & & & & & \\
\hline $\mathrm{ES}_{7}$ & $0.407 * *$ & $0.226 *$ & $-0.504 * *$ & $0.331^{* *}$ & $0.367^{* *}$ & 0.218 * & 0.333 ** & 1 & & & & & \\
\hline $\mathrm{ES}_{8}$ & $-0.516^{* *}$ & $-0.755^{* *}$ & $0.919^{* *}$ & $-0.869 * *$ & -0.133 & -0.207 & -0.161 & $-0.542 * *$ & 1 & & & & \\
\hline $\mathrm{ES}_{9}$ & $0.333 * *$ & $0.660 * *$ & $-0.779 * *$ & $0.818^{* *}$ & $0.244 *$ & $0.338^{* *}$ & 0.103 & $0.527^{* *}$ & $-0.926 * *$ & 1 & & & \\
\hline $\mathrm{ES}_{10}$ & 0.090 & 0.325 ** & -0.022 & $0.322 * *$ & -0.185 & $0.619 * *$ & -0.173 & -0.100 & -0.169 & 0.192 & 1 & & \\
\hline $\mathrm{ES}_{11}$ & $0.314 * *$ & 0.026 & -0.111 & 0.036 & -0.013 & -0.096 & 0.995 ** & $0.278 *$ & -0.108 & 0.067 & -0.082 & 1 & \\
\hline $\mathrm{ES}_{12}$ & $0.390 * *$ & 0.232 & $-0.366^{* *}$ & $0.285^{*}$ & -0.531 ** & $-0.433^{* *}$ & 0.099 & $0.459 * *$ & $-0.411^{* *}$ & $0.343^{\text {** }}$ & -0.068 & 0.151 & 1 \\
\hline
\end{tabular}

$\mathrm{ES}_{1}$ : Living energy consumption; $\mathrm{ES}_{2}$ : Living raw coal consumption; $\mathrm{ES}_{3}$ : Living power consumption; $\mathrm{ES}_{4}$ : Energy consumption of scale-enterprises; $\mathrm{ES}_{5}$ : Raw coal consumption of scale-enterprises; $\mathrm{ES}_{6}$ : Thermal consumption of scale-enterprise; $\mathrm{ES}_{7}$ : Power consumption of scale-enterprises; $\mathrm{ES}_{8}$ : Ratio for $\mathrm{ES}_{2} / \mathrm{ES}_{1} ; \mathrm{ES}_{9}$ : Ratio for $\mathrm{ES}_{3} / \mathrm{ES}_{1} ; \mathrm{ES}_{10}$ : Ratios for $\mathrm{ES}_{5} / \mathrm{ES}_{4} ; \mathrm{ES}_{9}$ : Ratios for $\mathrm{ES}_{6} / \mathrm{ES}_{4} ; \mathrm{ES}_{10}$ : Ratio for $\mathrm{ES}_{7} / \mathrm{ES}_{4}$. Note: $: p<0.05 ;{ }^{* *}: p<0.01$.

\section{Discussion}

\subsection{Pollution Status}

Henan province was supposed to be one of the most polluted and heavy polluted regions in China [22]. AQI values in the 17 municipalities of Henan province were always higher than the second standard for HJ663-2013 except for Xinyang during 2016 to 2018, although the AQI values decreased in the recent three years. Urban expansion, economic growth and irrational economic structure, high energy consumption and unreasonable energy structure were supposed to be the three main reasons for these trends $[1,2,8,15,22]$. The intensive emissions induced by a high population density, coal combustion and biomass burning for residential heating, as well as stagnant meteorological conditions that limit the dilution and dispersion of air pollutants, were the main reasons for the AQI values in the winter [9,27-29].

The nationwide implementation of desulfurization systems led to the decreasing trends for $\mathrm{SO}_{2}$ from 2003 to 2017 [30]. Inversely, $\mathrm{NO}_{2}$ contents in most municipalities increased somewhat in the past three years, although strict regulations on $\mathrm{NO}_{\mathrm{x}}$ emissions from power plants and heavy industry that led to the reduction of industrial air pollutants (Table 2) [31-33], which indicated that nonindustrial sources accounted for a greater proportion of the $\mathrm{NO}_{2}$. The formation rate of $\mathrm{O}_{3}$ depends on photochemical reactions, which are affected by solar radiation, temperature, and the emissions of 
precursors ( $\mathrm{NO}_{\mathrm{x}}$ and VOCs) $[31,32,34,35]$, leading to the linearly increasing trends for $\mathrm{O}_{3}$ contents in recent years.

In addition, it was the regional synergistic effects for air pollutants emission that caused the air pollution status in Henan province to be more significant, since air pollution in the surrounding province, such as Hebei province, Shanxi province, and Shandong province were always serious in the past years $[1,4-6,13,15,18,22]$.

\subsection{Driving Forces}

There are many researchers throughout the world devoted to studying the driving factors of air pollution. The research of Azimi et al. (2018) indicated that coal consumption, power generation, power intensity of GDP, and per capita GDP were four urban development drivers of per capita $\mathrm{SO}_{2}$ emissions, and the intensity of gasoline consumption, proportion of gasoline vehicles, vehicle use in urban populations, and urbanization rate were the four urban development drivers of per capita $\mathrm{NO}_{\mathrm{x}}$ in China [18]. In addition, topography, climate, industrial structure, population size and density, GDP, GDP of secondary industry, energy consumption, size of urban area, and transportation could also make great contributions to air pollution in a country or region [36-41]. However, only a single air pollution driving factor, or a few factors, were discussed in these studies, leading to some limitations on their conclusions.

Henan province is one of the most polluted regions in China [22]. Furthermore, there are evidences that the driving forces, including UDPG, EGCIS, and ECGSC, are the root reasons for serious air pollution in Henan province. Obviously, air pollution has important effects on the socioeconomic systems in Henan province. Therefore, the driving forces of urban systems, including UDPG, EGCIS, and ECGSC, are the root reasons for air pollution in Henan province (Figure 2).

\subsubsection{Urban Development and Population Growth Potential}

The UDPG index was the integrated index for urbanization rate, GDP, per capita GDP, urban population, and vehicle numbers. This parameter could express the status of UDPG quantitatively, and was significantly positively correlated to AQI values in the 17 municipalities of Henan province (Table 4). Therefore, UDPG was an indicator parameter that could reflect the change trends for air quality in Henan province. The main reasons were as follows:

First, unprecedented urbanization aggravated the sharp depletion of energy and resources, which then increased air pollutant emissions [18,42-46]. Even worse, the urban heat island effect not only affects the energy demand for cooling and heating, but also hampers air pollutant diffusion to a great extent $[41,46]$. Therefore, the air quality in the 17 municipalities of Henan province deteriorated in recent years (Figure 2).

Second, previous studies have shown that GDP could affect air pollution in a city or region. GDP (including per capita GDP) in Henan province grew greatly along with high energy consumption (coal has been the primary energy source in recent decades) and high air pollutant emissions.

Third, since ownership of vehicles in the 17 municipalities of Henan province has grown dramatically in recent years, traffic-related air pollution has played an increasingly significant role in the air quality. For instance, increasing trends of $\mathrm{NO}_{2}$ and $\mathrm{O}_{3}$ concentrations were observed from 2006 to 2017, and the PWA of $\mathrm{NO}_{2}$ increased slightly, while there was a linear increase in $\mathrm{O}_{3}-8 \mathrm{~h}$ in this province from 2013 to 2017.

Fourth, urban populations affected air quality significantly in some regions or the whole country in China [47]. A correlation analysis indicated that no significant correlations between AQI values and the total population quantities were observed, while AQI values were closely correlated to urban populations in the 17 municipalities of Henan province from 2003 to 2017 (Table 4). The main reasons were as follows: (1) The total population varied slightly due to the birth control policy of the past three decades, while there were unprecedented growth rates for urban populations, which put great pressure on air quality in these municipalities [44]; (2) the huge population base, accompanied by its 
high demands for energy and resources, also contributed to the worsening air conditions [48]; (3) the chain effects of high population, rapid urbanization, and ever-increasing energy demands decreased the air pollution status for the 17 municipalities of Henan province.

\subsubsection{Economic Growth and Change of Industrial Structure Potential}

Due to tremendous economic growth, the air quality of most cities in China has declined in the past 10 years $[1,18,49]$. Tourism and catering, with their high energy demand and high pollution emission intensity, mainly accounted for the increase in tertiary industrial growth (Table 5). Although secondary industrial outputs were significantly correlated to AQI values in the 17 municipalities of Henan province $(p<0.01)$, the values of the correlation coefficients were much lower than those of the tertiary industrial outputs because of more government control measures, much stricter control standards, and higher levels of end-pipe treatment [50]. The application of pesticides and fertilizers, as well as straw combustion during the harvest seasons, led to the close correlation between the AQI values and the primary industrial outputs in Henan province, which is a largely agricultural province.

Due to the development of tertiary industry and restrictions on industry, the levels of air pollution in Henan province were significantly positively correlated to the ratios of tertiary industry $(p<0.01)$, while there were significantly negative correlations between pollution levels and the ratios of primary industry or secondary industry $(p<0.01)$.

\subsubsection{Energy Consumption Growth and Structure Change Potential}

ECGSC played a crucial role in the variation of air quality in Henan province, and the main reasons were as follows:

First, coal-dominated energy production and consumption exacerbated the air pollution levels in the 17 municipalities of Henan province since coal combustion greatly contributed to the increase of air pollutants contents.

Second, the increasing energy demand arising from high population density, fast economic growth, and rapid urbanization accelerated the emissions of air pollutants in Henan province. Since energy consumption is significantly positively correlated to population, urbanization rate, GDP, output of primary industry, output of secondary industry, output of tertiary industry, and output of construction $(p<0.01)$, high population density, continuous economic growth, and rapid urbanization promoted unprecedented growth in the demand energy, which led to higher emissions of air pollutants and the deterioration of air quality, i.e., both AQI values and air pollution risk levels were significantly positively correlated with energy consumption $(p<0.05)$. Furthermore, ever-increasing energy consumption, especially coal consumption, increased air pollution in these 17 municipalities. Compared with industrial energy consumption, household energy consumption had a much greater impact on the air quality status in the 17 municipalities of Henan province.

Third, there were close correlations between industrial energy consumption and air pollution levels because industrial energy consumption was significantly positively correlated with the discharge amount of $\mathrm{SO}_{2}$, industrial waste gas, and $\mathrm{NO}_{\mathrm{x}}(p<0.01)$.

Therefore, close correlations between energy consumption and air pollution were observed in the past 10 years, with coal consumption dominating energy consumption structure playing a crucial role in the deterioration of air quality in Henan province. 


\subsection{Harmful Effects of Air Pollution}

Harmful effects of air pollution, including related diseases, fires, and traffic, were investigated by statistical methods (Table 8). Air pollution can trigger various physiological and psychological problems, as discussed by researchers around the world [2,4,5,51]. The relationship between air quality and related diseases (including respiratory disorders, cancer, heart disease, and nervous system disorders) was analyzed in the 17 municipalities of Henan province. Although significantly negative correlations were observed between mortality from respiratory disorders and AQI values $(p<0.01)$, respiratory disorders were still the most common illnesses caused by air pollution in the 17 municipalities of Henan province. The main reasons were as follows: (1) Admission rates for respiratory disorders were always the highest among all diseases; (2) it was indicated that several related diseases, i.e., lung cancer, could be initiated by respiratory disorders since there were significantly positive correlations between mortality from respiratory disorders and all related diseases $(p<0.01)$; and (3) mortality from respiratory disorders was significantly positively correlated with that from cancer, which was significantly positively correlated to TEAP $(p<0.01)$. Although no close correlations were observed between mortality from cancer and AQI values, mortality from cancer was significantly positively correlated to TEAP in the 17 municipalities of Henan province $(p<0.01)$. Mortality from heart diseases and nervous system disorders was significantly positively correlated to AQI values in the 17 municipalities of Henan province, which indicated that these two kinds of diseases are closely related to air pollution.

The frequency of fire disasters in the 17 municipalities of Henan province was significantly positively correlated to AQI values $(p<0.01)$, and the obvious decrease in visibility might be a major cause for the increase of their frequency. There were significantly negative correlations between AQI values and passenger volume (passenger turnover) in the 17 municipalities of Henan province $(p<0.01$ ), and the frequency of public transportation vehicles and the population decreased significantly as AQI values increased if they were higher than the standards. Such inverse correlation relationships were observed for freight transport and AQI values (Table 8 ) because freight transport was the main reason for the deterioration of air quality $(p<0.01)$ in this province. 
Table 8. DPSIR model and its influence parameters in the 17 municipalities in Henan province.

\begin{tabular}{|c|c|c|c|c|c|c|c|c|c|c|c|c|c|c|c|c|c|c|c|c|}
\hline Items & DFI & UDPG & EGCIS & ECGSC & TEAP & IEAP & $\mathrm{AQI}$ & $\mathrm{PM}_{2.5}$ & $\mathbf{P M}_{10}$ & $\mathrm{SO}_{2}$ & $\mathrm{NO}_{2}$ & $\mathrm{CO}$ & $\mathrm{O}_{3}-8 \mathrm{~h}$ & $\mathbf{R}$ & K-H & Fire & $\mathrm{HX}$ & ZL & $\mathrm{XZ}$ & SJ \\
\hline DFI & 1 & & & & & & & & & & & & & & & & & & & \\
\hline UDPG & $\underset{* *}{0.884}$ & 1 & & & & & & & & & & & & & & & & & & \\
\hline EGCIS & $756^{* *}$ & 0.488 & 1 & & & & & & & & & & & & & & & & & \\
\hline ECGSC & $\underset{* *}{0.607}$ & $\underset{* *}{0.389}$ & 0.221 * & 1 & & & & & & & & & & & & & & & & \\
\hline TAPE & 0.321 & $0.434^{*}$ & -0.106 & 0.202 & 1 & & & & & & & & & & & & & & & \\
\hline IAPE & -0.020 & -0.027 & -0.104 & $0.238^{*}$ & 0.090 & 1 & & & & & & & & & & & & & & \\
\hline $\mathrm{AQI}$ & 0.601 & $\underset{* *}{0.537}$ & $\underset{* *}{0.387}$ & $\underset{* *}{0.452}$ & 0.194 & -0.130 & 1 & & & & & & & & & & & & & \\
\hline $\mathrm{PM}_{2.5}$ & $\underset{*}{-0.316}$ & $\underset{*}{-0.296}$ & -0.213 & 0.088 & 0.088 & $\begin{array}{c}0.463 \\
* *\end{array}$ & 0.303 * & 1 & & & & & & & & & & & & \\
\hline $\mathrm{PM}_{10}$ & 0.214 & 0.166 & 0.161 & 0.100 & 0.148 & 0.069 & $\begin{array}{c}0.430 \\
* *\end{array}$ & 0.234 & 1 & & & & & & & & & & & \\
\hline $\mathrm{SO}_{2}$ & $\underset{* *}{-0.736}$ & $\underset{* *}{-0.711}$ & $\underset{* *}{-0.439}$ & $\underset{* *}{-0.400}$ & -0.143 & -0.054 & $\underset{* *}{-0.488}$ & $\underset{* *}{0.396}$ & -0.178 & 1 & & & & & & & & & & \\
\hline $\mathrm{NO}_{2}$ & $\begin{array}{c}-0.236 \\
*\end{array}$ & $\begin{array}{c}-0.275 \\
*\end{array}$ & -0.092 & -0.071 & -0.115 & -0.224 & -0.136 & -0.039 & $\underset{*}{-0.266}$ & $\underset{* *}{0.432}$ & 1 & & & & & & & & & \\
\hline $\mathrm{CO}$ & 0.277 & 0.140 & 0.276 & -0.035 & 0.223 & 0.039 & 0.113 & 0.267 & 0.126 & $\underset{*}{-0.376}$ & -0.267 & 1 & & & & & & & & \\
\hline $\mathrm{O}_{3}-8 \mathrm{~h}$ & $0.320 *$ & 0.364 & 0.097 & -0.082 & 0.089 & -0.495 & -0.121 & -0.200 & -0.027 & $-\underset{* *}{-0.539}$ & 0.113 & -0.213 & 1 & & & & & & & \\
\hline $\mathrm{R}$ & 0.668 & $\underset{* *}{0.613}$ & 0.436 & 0.464 & 0.266 & -0.054 & $\underset{* *}{0.956}$ & $\underset{* *}{0.356}$ & $\underset{* *}{0.430}$ & $\underset{* *}{-0.627}$ & $\underset{*}{-0.233}$ & 0.098 & -0.164 & 1 & & & & & & \\
\hline K-H & $\underset{* *}{0.505}$ & $\underset{* *}{0.381}$ & $\underset{* *}{0.495}$ & $\underset{* *}{0.268}$ & 0.184 & -0.043 & 0.135 & -0.186 & -0.006 & $-\underset{* *}{-0.387}$ & -0.127 & 0.171 & 0.162 & 0.170 & 1 & & & & & \\
\hline Fire & 0.387 & $\underset{* *}{0.353}$ & $\underset{* *}{0.312}$ & $0.207^{*}$ & 0.617 & 0.141 & $\underset{* *}{0.483}$ & 0.034 & $0.257^{*}$ & $\underset{*}{-0.231}$ & $\underset{*}{-0.274}$ & 0.095 & $\underset{*}{-0.300}$ & $\underset{* *}{0.523}$ & $0.234^{*}$ & 1 & & & & \\
\hline HX & -0.753 & -0.740 & -0.521 & -0.410 & -0.236 & -0.015 & -0.641 & 0.128 & -0.104 & 0.726 & 0.175 & -0.271 & -0.237 & -0.704 & $\underset{*}{-0.273}$ & $\underset{*}{-0.299}$ & 1 & & & \\
\hline $\mathrm{ZL}$ & -0.040 & -0.086 & -0.069 & 0.121 & -0.157 & -0.016 & 0.088 & 0.103 & 0.126 & 0.073 & -0.086 & -0.261 & -0.129 & 0.076 & 0.068 & 0.162 & $\begin{array}{c}0.469 \\
* *\end{array}$ & 1 & & \\
\hline$X Z$ & $\underset{* *}{0.345}$ & $\underset{* *}{0.306}$ & $0.207 *$ & $\underset{* *}{0.281}$ & -0.147 & -0.135 & $\underset{* *}{0.480}$ & -0.026 & 0.206 & $\underset{* *}{-0.409}$ & -0.228 & -0.219 & -0.012 & $\underset{* *}{0.499}$ & $\underset{* *}{0.284}$ & $\underset{* *}{0.335}$ & 0.017 & $\underset{* *}{0.755}$ & 1 & \\
\hline SJ & $\begin{array}{c}0.285 \\
* * \\
\end{array}$ & 0.172 & $0.223 *$ & $\begin{array}{c}0.284 \\
* * \\
\end{array}$ & -0.238 & 0.237 & 0.172 & 0.160 & 0.205 & $\begin{array}{c}-0.266 \\
* \\
\end{array}$ & $\begin{array}{c}-0.263 \\
* \\
\end{array}$ & -0.289 & -0.120 & $0.244^{*}$ & $\underset{* *}{0.378}$ & $\underset{* *}{0.300}$ & 0.124 & $\underset{* *}{0.626}$ & $\underset{* *}{0.665}$ & 1 \\
\hline
\end{tabular}




\subsection{Air Pollution Prediction Model}

As discussed above, the interactions among DFI, TEAP, IEAP, AQI, air pollutants, $R$, traffic, fire disasters, and related diseases determined the rise in air pollution risk in Henan province. As the DPSIR model demonstrated, it was obvious that the driving forces, which originated from UDPG, EGCIS, and ECGSC, promoted the discharge of air pollutants since UDPG and ECGSC were significantly positively correlated to total emissions of air pollutants and industrial emissions of air pollutants $(p<0.05)$, respectively.

$$
\begin{aligned}
& T E A P=0.051 \times U D P G+1.287 \\
& I E A P=0.194 \times E C G S C+1.528
\end{aligned}
$$

Furthermore, a Pearson correlation indicated that levels of air pollution were also determined by UDPG, EGCIS, and ECGSC (Tables 4-6 and Table 8), and the prediction model for air pollution in Henan province was based on the multiple linear regression analysis method using statistical analysis software SPSS 19.0.

$$
\begin{gathered}
A Q I=4.251 \times D F I+66.229 \\
R=0.0816 \times D F I+0.219 \\
A Q I=2.496 \times U D P G+3.525 \times E C G S C+67.911 \\
R=0.057 \times U D P G+0.061 \times E C G S C+0.171
\end{gathered}
$$

The integrated risk $(\mathrm{R})$, including traffic, fire disasters, and related diseases, was also affected by both DFI and AQI values; the specific reasons were as follows: (1) The R and AQI values in Henan province were linearly correlated to DFI, UDPG, and ECGSC in 2003 to 2017 ( $p<0.01$, Equations (7)-(10)), which indicated that the integrated risks were directly related to air pollution driven by DFI in this province, i.e., the growth rate for the $\mathrm{R}$ and $\mathrm{AQI}$ values were $0.0816 \mathrm{DFI}^{-1}$ and $4.251 \mathrm{DFI}^{-1}$, respectively; (2) the visibility decreased as air pollution increased, resulting in more traffic and an increased frequency of fire disasters in the 17 municipalities in 2003 to 2017 (Table 8); (3) $\mathrm{PM}_{2.5}$, as the major pollutant, was found to be correlated with the incidence of respiratory disorders, nervous system disorders, cancer, and cardiovascular disease by experts around the world [7,49]; and (4) the linear increase in $\mathrm{O}_{3}-8 \mathrm{~h}$ contents, which originated from air pollution and urban development in Henan province, could increase the incidence of respiratory disorders, cancer, and cardiovascular disease.

\section{Conclusions}

To investigate the 3D spatiotemporal features of air quality in the 17 municipalities of Henan province, China, historical data of AQI values, air pollutants $\left(\mathrm{PM}_{2.5}, \mathrm{PM}_{10}, \mathrm{SO}_{2}, \mathrm{NO}_{2}, \mathrm{CO}\right.$, and $\mathrm{O}_{3}-8 \mathrm{~h}$ ) contents, and R levels from 2003 to 2018 were analyzed in this study. Ascending trends of AQI and $R$ values, with a peak in 2015, were observed in Henan province from 2003 to 2018, and there were increasing trends for annual concentrations of all the air pollutants except $\mathrm{SO}_{2}$ in this period. The annual population-weighted average (PWA) values of $\mathrm{PM}_{2.5}, \mathrm{PM}_{10}, \mathrm{NO}_{2}$, and $\mathrm{O}_{3}-8 \mathrm{~h}$ in Henan province were always higher than the CAAQs II in 2013 to 2017, i.e., the annual population-weighted-average (PWA) values of $\mathrm{PM}_{2.5}, \mathrm{PM}_{10}$, and $\mathrm{O}_{3}$ in Henan province were $0.081(0.073,0.066) \mathrm{mg} \mathrm{m}^{-3}, 0.135$ (0.127, $0.117) \mathrm{mg} \mathrm{m}^{-3}, 0.150(0.165,0.183) \mathrm{mg} \mathrm{m}^{-3}$, and $0.403(0.405,0.402) \mathrm{mg} \mathrm{m}^{-3}$, respectively, in 2015 (2016, 2017). Among these, $\mathrm{PM}_{2.5}$ and $\mathrm{PM}_{10}$ were the major pollutants since they were always at high levels and were significantly positively correlated to AQI and R values $(p<0.05)$. Even worse, there was a linear increase in $\mathrm{O}_{3}-8 \mathrm{~h}$ contents in Henan province from 2013 to 2017. A statistical analysis indicated that changes in monthly moving average AQI values conformed to a U-shaped pattern with the highest values in the winter (from December to February) and the lowest ones in the summer (from June to August). Triple peaks for AQI values at 8:00-10:00 a.m., 6:00-8:00 p.m., and 2:00-4:00 p.m. in the representative municipalities were linked to the periods of morning and evening traffic, as well as photochemical process. The annual average AQI values in Henan province decreased from 
municipalities in the northwest (Anyang, Zhengzhou, and Jiaozuo, with annual average AQI values of $124.84,115.62$, and 115.65 in 2018) to those in the southeast (Zhumadian and Xinyang, with annual average AQI values of 104.65 and 97.51 in 2018). The same trends were observed for $R$ values and exceeding-standard days in Henan province, i.e., in 2018, the R values (exceeding-standard days) in Anyang, Zhengzhou, and Jiaozuo were 1.33 (201), 1.04 (180), and 1.19 (186), while those in Zhumadian and Xinyang were 0.97 (156) and 0.82 (133), respectively.

The driving force-pressure-state-influence-response (DPSIR) model for assessing socioeconomic forces driving air pollution was constructed using 48 correlative concrete parameters for 2003 to 2017 in Henan province, China. The too-rapid growth of DFI induced by UDPG (synthetic evaluation index for population, urbanization rate, GDP, PCGDP, and vehicle ownership), EGCIS (synthetic evaluation index for GDP, primary industry, secondary industry, tertiary industry, industry, construction, tourism, ratios of primary industry in GDP, ratios of secondary industry in GDP, and ratios of tertiary industry in GDP) and ECGSC (synthetic evaluation index for $\mathrm{ES}_{1}, \mathrm{ES}_{2}, \ldots \mathrm{ES}_{12}$ ) led to a direct increase in the atmospheric pollution burden, i.e., the values of UDPG and ECGSC were significantly correlated to TEAP (PCA results for total emissions of $\mathrm{SO}_{2}, \mathrm{NO}_{x}$, and dust) and IEAP (PCA results for industrial emissions of $\mathrm{SO}_{2}$, waste gas, $\mathrm{NO}_{\mathrm{x}}$, and dust), respectively, in Henan province $(p<0.05)$. Furthermore, the prediction models for $\mathrm{AQI}$ and $\mathrm{R}$ values in Henan province, with the growth rates of $4.2512 \mathrm{DFI}^{-1}$ and $0.0816 \mathrm{DFI}^{-1}$, respectively, were simulated by a multiple linear regression analysis. Although no significant correlations were observed between the annual amount of TEAP and the air pollutants concentrations, the cumulative effects of air pollutant emissions made a great contribution to the air quality in different municipalities of Henan province. Industrial sources contributed to annual $\mathrm{PM}_{2.5}$ levels as IEAP values were significantly positively correlated to annual $\mathrm{PM}_{2.5}$ concentrations $(p<0.01)$. Accordingly, the integrated risks of air pollution in Henan province, including traffic, fire disasters, respiratory disorders, heart disease, and nervous system disorders, originated from the severe air pollution (high levels of $\mathrm{AQI}$ values, $\mathrm{PM}_{2.5}, \mathrm{PM}_{10}, \mathrm{NO}_{2}$ ).

Author Contributions: Conceptualization, X.C.; Data curation, X.C., C.F. and Y.H.; Formal analysis, X.C. and M.W.; Funding acquisition, X.C.; Investigation, X.C., C.F., J.W. and Y.H.; Methodology, X.C. and M.W.; Supervision, X.C.; Writing-original draft, X.C.; Writing-review \& editing, X.C. All authors have read and agreed to the published version of the manuscript.

Funding: This work is funded by National Natural Science Foundation of China (71673076), Special Program of Public Safety (660113/016/004), Procuring and Bidding System Program of Jiaozuo (JZZ201911Z) and Annual Project of Henan Polytechnic University (SKND2019-19).

Conflicts of Interest: The authors declare no conflict of interest.

\section{References}

1. Liu, Y.P.; Wu, J.G.; Yu, D.Y. Disentangling the complex effects of socioeconomic, climatic, and urban form factors on air pollution: A case study of China. Sustainability 2018, 10, 776. [CrossRef]

2. Hao, Y.; Peng, H.; Temulun, T.; Liu, L.Q.; Mao, J.; Lu, Z.N.; Chen, H. How harmful is air pollution to economic development? New evidence from $\mathrm{PM}_{2.5}$ concentrations of Chinese cities. J. Clean. Prod. 2018, 172, $743-757$. [CrossRef]

3. Cariolet, J.M.; Colombert, M.; Vuillet, M.; Diab, Y. Assessing the resilience of urban areas to traffic-related air pollution: Application in Greater Paris. Sci. Total Environ. 2018, 615, 588-596. [CrossRef] [PubMed]

4. Tang, G.Q.; Zhao, P.S.; Wang, Y.H.; Gao, W.K.; Cheng, M.T.; Xin, J.Y.; Li, X.; Wang, Y.S. Mortality and air pollution in Beijing: The long-term relationship. Atmos. Environ. 2017, 150, 238-243. [CrossRef]

5. Ma, Y.X.; Zhao, Y.X.; Yang, S.X.; Zhou, J.D.; Xin, J.Y.; Wang, S.G.; Yang, D.D. Short-term effects of ambient air pollution on emergency room admissions due to cardiovascular causes in Beijing, China. Environ. Pollut. 2017, 230, 974-980. [CrossRef]

6. Gu, Y.; Yim, S.H.L. The air quality and health impacts of domestic trans-boundary pollution in various regions of China. Environ. Int. 2016, 97, 117-124. [CrossRef]

7. Tao, Y.; Mi, S.Q.; Zhou, S.H.; Wang, S.G.; Xie, X.Y. Air pollution and hospital admissions for respiratory diseases in Lanzhou, China. Environ. Pollut. 2014, 185, 196-201. [CrossRef] 
8. Sun, C.W.; Luo, Y.; Li, J.L. Urban traffic infrastructure investment and air pollution: Evidence from the 83 cities in China. J. Clean. Prod. 2018, 172, 488-496. [CrossRef]

9. Song, C.B.; He, J.J.; Wu, L.; Jin, T.S.; Chen, X.; Li, R.P.; Ren, P.P.; Zhang, L.; Mao, H.J. Health burden attributable to ambient $\mathrm{PM}_{2.5}$ in China. Environ. Pollut. 2017, 223, 575-586. [CrossRef]

10. Li, L.; Lei, Y.L.; Pan, D.Y.; Yu, C.; Si, C.Y. Economic evaluation of the air pollution effect on public health in China's 74 cities. Springerplus 2016, 5, 402. [CrossRef]

11. Guan, W.J.; Zheng, X.Y.; Chung, K.F.; Zhong, N.S. Impact of air pollution on the burden of chronic respiratory diseases in China: Time for urgent action. Lancet 2016, 388, 1939-1951. [CrossRef]

12. Rohde, R.A.; Muller, R.A. Air pollution in China: Mapping of concentrations and sources. PLoS ONE 2015, 10, e0135749. [CrossRef] [PubMed]

13. Wang, Y.; Liu, H.W.; Mao, G.Z.; Zuo, J.; Ma, J.L. Inter-regional and sectoral linkage analysis of air pollution in Beijing-Tianjin-Hebei (Jing-Jin-Ji) urban agglomeration of China. J. Clean. Prod. 2017, 165, 1436-1444. [CrossRef]

14. Rao, S.; Klimont, Z.; Smith, S.J.; Van Dingenen, R.V.; Dentener, F.; Bouwman, L.; Riahi, K.; Amann, M.; Bodirsky, B.L.; Vuuren, D.P.; et al. Fature air pollution in the shared socio-economic pathways. Glob. Environ. Chang. 2017, 42, 346-358. [CrossRef]

15. Lyu, W.; Li, Y.; Guan, D.B.; Zhao, H.Y.; Zhang, Q.; Liu, Z. Driving forces of Chinese primary air pollution emissions: An index decomposition analysis. J. Clean. Prod. 2016, 133, 136-144. [CrossRef]

16. Li, W.; Sun, S. Air pollution driving factors analysis: Evidence from economically developed area in China. Environ. Prog. Sustain. Energy 2016, 35, 1231-1239. [CrossRef]

17. Rosu, A.; Constantin, D.E.; Georgescu, L. Air pollution level in Europe caused by energy consumption and transportation. J. Environ. Prot. Ecol. 2016, 17, 1-8.

18. Azimi, M.; Feng, F.; Yang, Y. Air pollution inequality and its sources in $\mathrm{SO}_{2}$ and $\mathrm{NO}_{\mathbf{x}}$ emissions among Chinese provinces from 2006 to 2015. Sustainability 2018, 10, 367. [CrossRef]

19. Basagaña, X.; Triguero-Mas, M.; Agis, D.; Pérez, N.; Reche, C.; Alastuey, A.; Querol, X. Effect of public transport strikes on air pollution levels in Barcelona (Spain). Sci. Total Environ. 2018, 610-611, 1076-1082. [CrossRef]

20. Gao, J.L.; Yuan, Z.W.; Liu, X.W.; Xia, X.M.; Huang, X.J.; Dong, Z.F. Improving air pollution control policy in China-A perspective based on cost-benefit analysis. Sci. Total Environ. 2016, 543, 307-314. [CrossRef]

21. Ning, G.C.; Wang, S.G.; Ma, M.J.; Ni, C.J.; Shang, Z.W.; Wang, J.X.; Li, J.X. Characteristics of air pollution in different zones of Sichuan Basin, China. Sci. Total Environ. 2018, 612, 975-984. [CrossRef] [PubMed]

22. Liu, Y.P.; Wu, J.G.; Yu, D.Y.; Hao, R.H. Understanding the patterns and drivers of air pollution on multiple time scales: The case of Northern China. Environ. Manag. 2018, 61, 1048-1061. [CrossRef] [PubMed]

23. Chen, A.; Chen, N.; Wu, Y.N. Modern Emergency Management Technology and System; Science Press: Beijing, China, 2011.

24. Renzi, M.; Cerza, F.; Gariazzo, C.; Agabiti, N.; Cascini, S.; Di Domenicantonio, R.; Davoli, M.; Forastiere, F.; Cesaroni, G. Air pollution and occurrence of type 2 diabetes in a large cohort study. Environ. Int. 2018, 112, 68-76. [CrossRef] [PubMed]

25. European Environment Agency (EEA). Halting the loss of biodiversity by 2010: Proposal for a first set of indicators to monitor progress in Europe; EEA Technical Report no. 11/2007; European Environment Agency: Copenhagen, Denmark, 2007.

26. Liu, Y.; Wang, S.J.; Qiao, Z.X.; Wang, Y.H.; Ding, Y.Y.; Miao, C.H. Estimating the dynamic effects of Socioeconomic development on industrial $\mathrm{SO}_{2}$ emissions in Chinese cities using a DPSIR causal framework. Resour. Conserv. Recy. 2019, 150, 104450. [CrossRef]

27. Jeong, J.I.; Park, R.J. Winter monsoon variability and its impact on aerosol concentrations in East Asia. Environ. Pollut. 2017, 221, 285-292. [CrossRef]

28. Wang, J.; Bi, X.H.; Feng, Y.C.; Zhang, Y.F.; Wu, J.H.; Lv, A.H. Pollution characteristics and source apportionment of $\mathrm{PM}_{2.5}$ during heavy pollution process in Urumchi city. Res. Environ. Sci. 2014, 27, 113-119.

29. Yang, Y.Q.; Wang, J.Z.; Gong, S.L.; Zhang, X.Y.; Wang, H.; Wang, Y.Q.; Wang, J.; Li, D.; Guo, J.P. PLAM-a meteorological pollution index for air quality and its applications in fog-haze forecasts in North China. Atmos. Chem. Phys. 2016, 16, 1353-1364. [CrossRef]

30. Van der, A.R.J.; Mijling, B.; Ding, J.; Koukouli, M.E.; Liu, F.; Li, Q.; Mao, H.; Theys, N. Cleaning up the air: Effectiveness of air quality policy for $\mathrm{SO}_{2}$ and $\mathrm{NO}_{2}$ emissions in China. Atmos. Chem. Phys. 2017, 17, 1772-1789. [CrossRef] 
31. Phalitnonkiat, P.; Sun, W.X.; Grigoriu, M.D.; Hess, P.; Samorodnitsky, G. Extreme ozone events: Tail behavior of the surface ozone distribution over the U.S. Atmos. Environ. 2016, 128, 134-146. [CrossRef]

32. Jaffe, D.A.; Zhang, L. Meteorological anomalies lead to elevated $\mathrm{O}_{3}$ in the western U.S. in June 2015. Geophys. Res. Lett. 2017, 44, 1990-1997. [CrossRef]

33. Liu, X.J.; Zhang, Y.; Han, W.X.; Tang, A.H.; Shen, J.L.; Cui, Z.L.; Vitousek, P.; Erisman, J.W.; Goulding, K.; Christie, P.; et al. Enhanced nitrogen deposition over China. Nature 2013, 494, 459-462. [CrossRef] [PubMed]

34. Pusede, S.E.; Cohen, R.C. On the observed response of ozone to $\mathrm{NO}_{\mathrm{x}}$ and VOC reactivity reductions in San Joaquin Valley California 1995-present. Atmos. Chem. Phys. 2012, 12, 8323-8339. [CrossRef]

35. Wang, T.; Xue, L.K.; Brimblecombe, P.; Lam, Y.F.; Li, L.; Zhang, L. Ozone pollution in China: A review of concentrations, meteorological influences, chemical precursors, and effects. Sci. Total Environ. 2017, 575, 1582-1596. [CrossRef] [PubMed]

36. Liu, M.M.; Huang, Y.N.; Ma, Z.W.; Jin, Z.; Liu, X.Y.; Wang, H.K.; Liu, Y.; Wang, J.N.; Jantunen, M.; Bi, J.; et al. Spatial and temporal trends in the mortality burden of air pollution in China: 2004-2012. Environ. Int. 2016, 98, 75-81. [CrossRef] [PubMed]

37. Xia, T.; Nitschke, M.; Zhang, Y.; Shah, P.; Crabb, S.; Hansen, A. Traffic-related air pollution and health co-benefits of alternative transport in Adelaide, South Australia. Environ. Int. 2015, 74, 281-290. [CrossRef]

38. Yuan, X.L.; Mu, R.M.; Zuo, J.; Wang, Q.S. Economic development, Energy Consumption, and Air Pollution: A Critical Assessment in China. Hum. Ecol. Risk Assess. 2015, 21, 781-798. [CrossRef]

39. Carlsten, C.; Rider, C.F. Traffic-related air pollution and allergic disease: An update in the context of global urbanization. Curr. Opin. Allergy Clin. Immunol. 2017, 17, 85-89. [CrossRef]

40. Wang, S.J.; Zhou, C.S.; Wang, Z.B.; Feng, K.S.; Hubacek, K. The characteristics and drivers of fine particulate matter $\left(\mathrm{PM}_{2.5}\right)$ distribution in China. J. Clean. Prod. 2017, 142, 1800-1809. [CrossRef]

41. Xu, X.Y.; González, J.E.; Shen, S.H.; Miao, S.G.; Dou, J.X. Impacts of urbanization and air pollution on building energy demands-Beijing case study. Appl. Energy 2018, 225, 98-109. [CrossRef]

42. Aunan, K.; Wang, S.X. Internal migration and urbanization in China: Impacts on population exposure to household air pollution (2000-2010). Sci. Total Environ. 2014, 481, 186-195. [CrossRef]

43. Lung, S.C.C.; Lee, C.R.; Hu, S.C. Inequality of Asian-type neighborhood environmental quality in communities with different urbanization levels. Environ. Sci. Policy 2014, 38, 1-10. [CrossRef]

44. Tan, P.H.; Chou, C.; Chou, C.C.K. Impact of urbanization on the air pollution "holiday effect" in Taiwan. Atmos. Environ. 2013, 70, 361-375. [CrossRef]

45. Fecht, D.; Fischer, P.; Fortunato, L.; Hoek, G.; De Hoogh, K.; Marra, M.; Hansell, A. Associations between air pollution and socioeconomic characteristics, ethnicity and age profile of neighborhoods in England and the Netherlands. Environ. Pollut. 2015, 198, 201-210. [CrossRef] [PubMed]

46. Liu, H.N.; Ma, W.L.; Qian, J.L.; Cai, J.Z.; Ye, X.M.; Li, J.H.; Wang, X.Y. Effect of urbanization on the urban meteorology and air pollution in Hangzhou. J. Meteorol. Res. 2015, 29, 950-965. [CrossRef]

47. Li, F.Y.; Xiao, X.L.; Xie, W.; Ma, D.W.; Song, Z.; Liu, K. Estimating air pollution transfer by interprovincial electricity transmissions: The case study of the Yangtze River Delta Region of China. J. Clean. Prod. 2018, 183, 56-66. [CrossRef]

48. Lou, C.R.; Liu, H.Y.; Li, Y.F.; Li, Y.L. Socioeconomic drivers of $\mathrm{PM}_{2.5}$ in the accumulation phase of air pollution episodes in the Yangtze River Delta of China. Int. J. Environ. Res. Public Health 2016, 13, 928. [CrossRef]

49. Zhang, M.; McSaveney, M.J. Is air pollution causing landslides in China? Earth Planet. Sci. Lett. 2018, 481, 284-289. [CrossRef]

50. Huo, H.; Zhang, Q.; Guan, D.; Su, X.; Zhao, H.Y.; He, K.B. Examining air pollution in China using production-and consumption-based emissions accounting approaches. Environ. Sci. Technol. 2014, 48, 14139-14147. [CrossRef]

51. Brandt, S.; Dickinson, B.; Ghosh, R.; Lurmann, F.; Perez, L.; Penfold, B.; Wilson, J.; Künzli, N.; McConnell, R. Costs of coronary heart disease and mortality associated with near-roadway air pollution. Sci. Total Environ. 2017, 601-602, 391-396. [CrossRef]

(C) 2019 by the authors. Licensee MDPI, Basel, Switzerland. This article is an open access article distributed under the terms and conditions of the Creative Commons Attribution (CC BY) license (http://creativecommons.org/licenses/by/4.0/). 